\title{
La reutilización de antigüedades en al-Ándalus: ¿recurso o discurso?*
}

\author{
The reuse of antiquities in al-Andalus: \\ resource or discourse?
}

\author{
Jorge Elices Ocón \\ Universidade Federal de São Paulo, Brasil \\ jorge.elices.ocon@gmail.com \\ ORCID iD: https://orcid.org/0000-0002-4794-7934
}

Enviado: 06-11-2019. Aceptado: 17-02-2020. Publicado online: 21-05-2021

Cómo citar este artículo / Citation: Elices Ocón, J. (2021). "La reutilización de antigüedades en al-Ándalus: ¿recurso o discurso?’. Archivo Español de Arqueología, 94, e06. DOI: https://doi.org/10.3989/aespa.094.021.06

RESUMEN: En el presente artículo se estudia la reutilización de antigüedades en al-Ándalus durante los siglos VIII-X. Se propone prestar atención al valor dado a los materiales a través de las fuentes escritas y arqueológicas, poniendo de manifiesto la existencia de una primera etapa donde la reutilización afecta a elementos arquitectónicos decorativos con un valor constructivo y decorativo, empleados además de forma masiva en los edificios. No obstante, a finales del siglo IX se detecta un cambio. Las antigüedades reutilizadas son singulares, como sarcófagos o estatuas, consideradas "maravillas" y capaces de evocar una reflexión sobre el pasado. Una fetua de finales del siglo IX ilustra acerca de este cambio y evidencia el control de los Omeyas sobre estas piezas, cuyo testimonio más destacado es el conjunto de antigüedades de Madinnat al-Zahrā'.

Palabras clave: Omeyas; alcázar; mezquita de Córdoba; Madīnat al-Zahrā'; estatuas; sarcófagos; fetuas.

ABSTRACT: This article studies the reuse of antiquities in al-Andalus during the VIII-X centuries. It puts forward to pay attention to the value given to the materials, considering written and archaeological sources, highlighting the existence of a first stage where reuse focused on decorative architectural elements with a constructive and decorative value, used massively in the buildings. However, at the end of the IX century it turned to be a change. The antiquities reused are distinctive, such as sarcophagi or statues, considered "mirabilia" and capable of evoking a reflection on the past. A fetua from the end of the ninth century illustrates about this change and points out the control of the Umayyads over these materials, whose most prominent testimony is the set of antiquities at Madinat al-Zahrā'.

Keywords: Umayyads; palace; mosque of Cordoba; Madinnat al-Zahrā'; statues; sarcophagi; legal response.

Copyright: (C) 2021 CSIC. Este es un artículo de acceso abierto distribuido bajo los términos de la licencia de uso y distribución Creative Commons Reconocimiento 4.0 Internacional (CC BY 4.0).

\footnotetext{
* Este artículo fue desarrollado gracias a una beca del gobierno estatal de São Paulo: FAPESP 2018/15102-7. Una versión preliminar fue presentada en el VII Congreso de Jóvenes Medievalistas celebrado en la Universidad de Oviedo los días 14-16 de octubre de 2019.
} 
Desde las últimas décadas, los estudios sobre reutilización de antigüedades durante la Alta Edad Media, específicamente en el mundo islámico, se han convertido en un importante campo de investigación. Se han desafiado los presupuestos tradicionales que apuntaban a un rechazo o desinterés del islam frente al pasado preislámico $\mathrm{y}$, en particular, a la representación figurada y al paganismo de la época anterior al islam o ȳāhiliyya (Webb, 2014) y se ha resaltado cuán temprana e importante es la práctica de la reutilización en el mundo islámico (Greenhalgh, 2009, 2012).

La península ibérica es un escenario central en estos estudios. El caso más paradigmático es la mezquita de Córdoba. Los trabajos de P. Cressier, Ch. Ewert y A. Peña, han puesto atención en analizar la disposición de los materiales en el oratorio, evidenciando la existencia de criterios de ordenación con base en los colores y decoraciones de fustes y capiteles, que servirían para jerarquizar determinados espacios (Ewert y Wisshak, 1981; Cressier, 1984, 1985, 1991, 2001; Ewert, 2009; Peña, 2009 y 2010). Según señalaba A. Peña, "la principal motivación para el uso de spolia en la mezquita de Córdoba debe haber sido de naturaleza ideológica" (Peña, 2009, p. 268). Se trataba del edificio con más material reutilizado del Mediterráneo en el siglo VIII, sin embargo, las fuentes árabes no mencionan esta reutilización tan significativa (Peña, 2010, p. 195).

Los trabajos que no se circunscriben a un ejemplo específico, sino que trazan una perspectiva global y comparativa son, en cambio, algo más puntuales (Morán Turina, 2010, pp. 23-50). En este sentido, el estudio elaborado por M. ${ }^{a}$ Ángeles Utrero e Issac Sastre ha supuesto una interesante novedad al reconsiderar la reutilización desde la disyuntiva necesidad o posibilidad, encuadrando su análisis dentro de los ciclos constructivos y tecnológicos. Ponían de manifiesto que la reutilización debe entenderse como un proceso iniciado ya en el siglo $\mathrm{V}$, motivado por el abandono de las canteras romanas y la pérdida o desuso de herramientas y conocimientos, que se prolonga durante toda la Antigüedad Tardía y parte de la Alta Edad Media. En su estudio atendían especialmente a las iglesias altomedievales. Los reinos cristianos del norte peninsular participaron de este proceso, aunque a una escala mucho más reducida. La mayoría de los ejemplos de reutilización deben adscribirse a la segunda mitad del siglo IX o comienzos del siglo X y los casos en los que cabe pensar en una concepción de las antigüedades más allá de su valor constructivo son muy escasos (Utrero y Sastre, 2012, p. 315).

Para el caso andalusí me parece interesante destacar un breve estudio de P. Cressier, donde analizaba varios casos de reutilización correspondientes tanto a al-Ándalus como al Norte de África, comprendidos entre los siglos VIII y X. En este trabajo se desprenden ya algunas de las preocupaciones que centran el debate hoy en día y que coinciden en gran medida con las nuevas perspectivas de análisis abiertas por $\mathrm{M}^{\mathrm{a}}{ }^{\mathrm{a}}$ Ángeles Utrero e Issac Sastre (Cressier, 2001). Por un lado, se recalca el aspecto metodológico, incidiendo en que "una vez detectado, todo caso de acarreo deberá someterse a una interpretación argumentada y sin prejuicio, que tendrá en cuenta la naturaleza del monumento y las condiciones históricas de su erección; única forma de asegurarse si conlleva una información histórica" (Cressier, 2001, p. 323). Por otro lado, P. Cressier distingue entre aquellos ejemplos de reutilización en los que se puede aducir una necesidad práctica y aquellos otros en los que la reutilización "es el resultado de una verdadera elección" que tiene que ver, fundamentalmente, "con el significado específico que se atribuye en un momento dado a las piezas en cuestión" (Cressier, 2001, p. 311).

La conclusión que se desprende de este rápido balance historiográfico es que, pese a los claros avances, la investigación parece focalizada en el debate sobre el porqué de la reutilización, según se destaque el componente pragmático o ideológico. Existe también un tratamiento dispar en torno a las fuentes disponibles para llevar a cabo estos estudios, ya sean escritas o arqueológicas, así como una preocupación compartida en torno a la metodología, los criterios y las perspectivas que deben ser consideradas a la hora de analizar la reutilización de determinadas piezas ${ }^{1}$.

Mi objetivo aquí es intentar ofrecer un panorama comprensible de los procesos de reutilización en al-Ándalus durante los siglos VIII-X, atendiendo al conjunto de fuentes disponibles, incorporando nuevas referencias y perspectivas de análisis y señalando los cambios más notables que nos permiten comprender el sentido dado a la reutilización y el significado otorgado a las piezas. De este modo, pondré de manifiesto la existencia de una primera etapa donde la reutilización afecta a elementos arquitectónicos decorativos con un valor constructivo y decorativo. En esta etapa, la reutilización constituye un recurso constructivo, en continuación con los procesos habituales desde época tardoantigua, así como un discurso de legitimación, acorde al "lenguaje de poder" importado por los Ome-

1 Las fuentes árabes no suelen ser consideradas, o aparecen como fuente secundaria. Su empleo responde a veces a la necesidad de ilustrar ejemplos más que a la propia argumentación y demostración de las hipótesis sostenidas. Se detecta también una tendencia a atribuir un valor ideológico a ejemplos de reutilización que ofrecen más dudas que certidumbres y responden a una mera necesidad y no tanto a una posibilidad o elección. 
yas desde Oriente, atendiendo al prestigio, la calidad y la cantidad de material reutilizado. No obstante, a finales del siglo IX se detecta un cambio significativo. Las antigüedades reutilizadas son singulares, como sarcófagos o estatuas, consideradas "maravillas" y capaces de evocar una reflexión sobre el pasado. Su hallazgo y reutilización parece estar regulado y orquestado por el poder. Finalmente, para profundizar en este punto de inflexión, analizaré una fetua de finales del siglo IX, que ilustra este cambio de paradigma y me detendré en considerar un ejemplo único, el conjunto de piezas de Madinat al-Zahrā', que evidencia el protagonismo de las antigüedades en la construcción material e ideológica del poder omeya en al-Ándalus.

\section{LA REUTILIZACIÓN COMO RECURSO Y DISCURSO}

La reutilización en al-Ándalus no puede ser desasociada de los procesos que conocemos en Oriente, en los que la península ibérica se encuadra a comienzos del siglo VIII. De este modo, la reutilización es un fenómeno estrechamente vinculado a los primeros califas omeyas, que hicieron un uso masivo de antigüedades, especialmente en las mezquitas de Jerusalén y Damasco, escenificando con ellas la implantación de un nuevo orden político y religioso (Finster, 2009; Greenhalgh, 2009, pp. 282-296 y 2012, pp. 259-283). Posteriormente, hacia mediados del siglo VIII, los 'Abbāsíes ocuparon el poder y no mostraron un uso tan destacado de spolia (Peña, 2010, p. 210). Esto es algo interesante. Quizás los 'Abbāsíes buscaban poner de manifiesto una ruptura, abriéndose a las influencias sasánidas y trasladando la capital a Bagdad. Ellos desarrollaron su propio lenguaje arquitectónico y político y la legitimación provenía de otros cauces diferentes. En cualquier caso, los elementos reutilizados no desaparecen por completo, simplemente cambian su significado y su uso, como señalaré más adelante.

La supervivencia de la dinastía omeya en la península ibérica, donde acaba recalando el príncipe 'Abd al-Raḥmān I supuso, sin embargo, la continuidad del "lenguaje de poder" omeya en al-Ándalus. De este modo, aunque la reutilización es un fenómeno bien atestiguado en Hispania durante época tardoantigua, lo cierto es que la llegada de los Omeyas significó un cambio de paradigma al respecto ${ }^{2}$. La construcción de la mezquita de Córdoba en el año 785 constituyó un

2 Un ejemplo significativo puede ser la tapa de sarcófago hallada en Carranque (Toledo), reutilizada como cubierta de una de las tumbas de la necrópolis visigoda del siglo VII: Fernández Ochoa et al., 2011. punto de inflexión. Fue la primera construcción omeya de entidad en la península, un edificio que contó con una especial vinculación con la dinastía (de hecho, todos los emires de al-Ándalus intervinieron de algún modo en ella) (Manzano, 2006, pp. 213-218). Para la construcción de los cimientos se emplearon sillares procedentes de cantera, mientras que el oratorio se erigió con columnas y capiteles reutilizados de cronología y origen dispar (Fig. 1) (Azuar, 2005, p. 152)

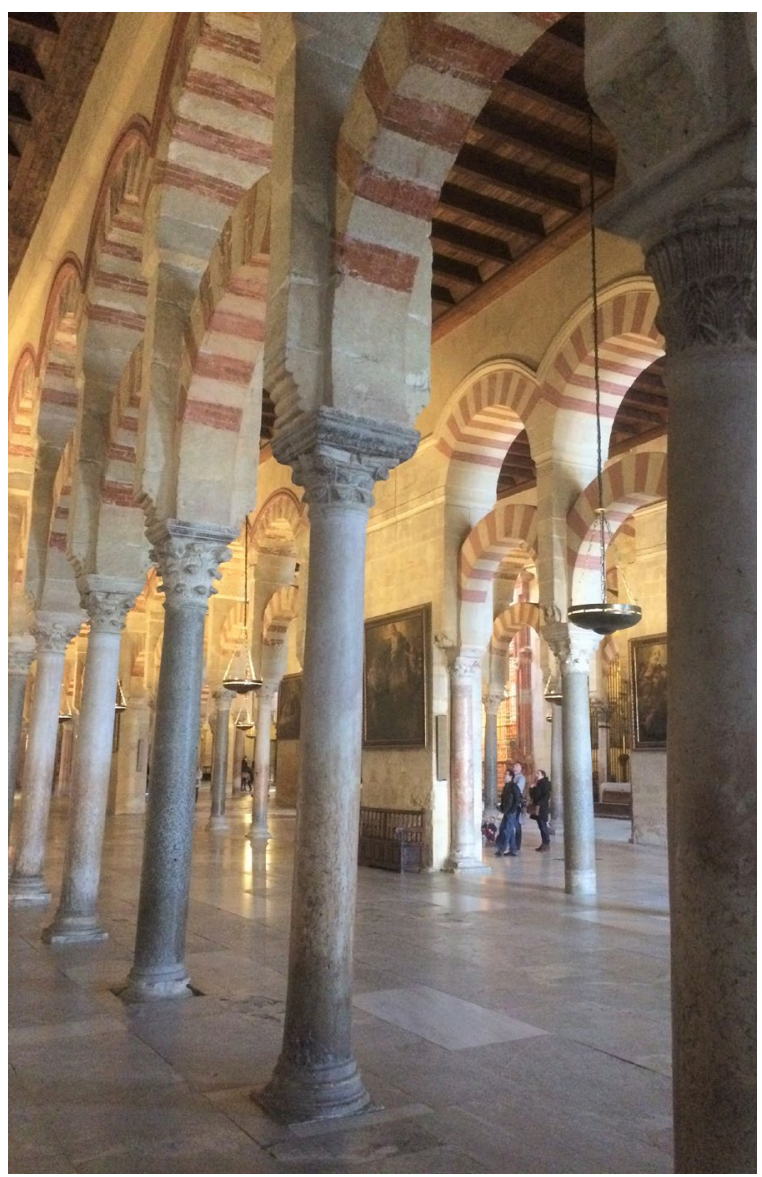

Figura 1. Columnas, capiteles y cimacios reutilizados en la primitiva mezquita construida por 'Abd al-Raḥmān I (fotografía del autor).

3 Parte de las columnas y capiteles provendrían quizás la de iglesias y basílicas de la propia Córdoba (Peña, 2009, pp. 255258 y 2010 , pp. 120-127) o de ciudades antiguas convertidas en auténticas canteras de material: Itálica o Écija e incluso lugares más lejanos como Cartagena y Tarragona. También se podría relacionar con el expolio del recinto de Cercadilla, donde se ha atestiguado el saqueo masivo de las estructuras de opus caementicium con vistas a la obtención de cal datadas a finales del siglo VIII, coincidiendo por tanto con la construcción de la mezquita: Hidalgo, 1996, p. 31, notas 24 y 56; Peña, 2010, p. 114. 
Se trata de una reutilización masiva, y justamente los números evidenciarían algo respecto a este "lenguaje del poder" y su discurso ideológico. A. Peña ya incidió en estos aspectos. El edificio empleaba un número de columnas muy significativo, 142, cuando años antes, en el 163/780, sabemos que el califa 'abbāsí al-Mahdī había remodelado la mezquita al-Aqșā de Jerusalén, alcanzado las 140 columnas (Peña, 2009, pp. 263-264 y 268-269, 2010, p. 174). Posteriormente, la ampliación de la mezquita por 'Abd al-Raḥmān II supuso el empleo tanto de fustes y capiteles reutilizados como de nuevos capiteles labrados ex profeso, que imitan a los antiguos con gran precisión y detalle (Cressier, 1991 y 2001, p. 319). En este caso se puede señalar además que parte del material antiguo reutilizado proviene de diferentes regiones y ciudades de al-Ándalus, como es el caso de varios capiteles emeritenses (De la Barrera, 1984, p. 48, no 64; Peña, 2009, pp. 255-256). De nuevo, además, la remodelación de la mezquita de la Cúpula de la Roca en Jerusalén en el 216/831 por el califa al-Ma'mūn o la construcción de la mezquita de Qayrawān en el 221/836 por los aglabíes, empleando un total de 220 columnas, motivaría la respuesta de 'Abd al-Raḥmān II que amplió la mezquita de Córdoba hasta las 222 columnas (Peña, 2009, pp. 263264 y 268-269, 2010, p. 215).

En definitiva, la mezquita de Córdoba atestigua la existencia de un discurso omeya que se construye literalmente con piezas de la antigüedad y se manifiesta desde el mismo momento en el que se afianza la dinastía en la península. La reutilización se centra especialmente en elementos arquitectónicos ornamentales y tiene un valor eminentemente constructivo, mientras que el componente ideológico se sustenta sobre todo en el carácter masivo de la reutilización. El discurso, sin embargo, no ahonda en la influencia o continuidad con respecto a la Antigüedad Clásica (Kinney, 2001, pp. 149-150), sino que se centra en oriente y en la rivalidad política y religiosa entre Omeyas y 'Abbāsíes. Estos aspectos evidencian un punto de inflexión en los procesos de reutilización vigentes hasta la fecha en la península, vinculado directamente a las nuevas técnicas y el lenguaje de poder importado por los Omeyas.

Junto con esta conexión con oriente, un segundo aspecto a destacar es la convivencia, desde el primer momento, de material reutilizado y material procedente de cantera, así como el valor constructivo otorgado a los materiales. Se reutilizan mayoritariamente elementos arquitectónicos decorativos, y las estatuas o inscripciones, que tal vez podrían suscitar otro tipo de valoración, se emplean también como material constructivo $^{4}$. La reutilización, particularmente del mármol, continúa siendo una necesidad, como ya ocurría desde época tardoantigua, y lo será hasta que las canteras sean explotadas de manera sistemática.

En la península, una de las primeras medidas llevadas a cabo tras la conquista islámica de Córdoba fue la reconstrucción de su puente y murallas, llevada a cabo en 719-720. Se trataba de una actuación destacada: el puente era un hito estratégico y garantizaba la conexión de la capital con la costa sur y el norte de África (Manzano, 2006, p. 71). El encargado de realizar estas obras habría sido el gobernador alSamh, siguiendo para ello instrucciones del califa de Damasco. Este había decretado que los sillares de la muralla sirvieran para reconstruir el puente, mientras que para reparar la cerca se utilizara ladrillo si no había suficiente piedra (Ajbār Maŷmū'a, 23-24/35; Ibn al-Qūtiyya, Ta'rīj, p. 178; Fath, 46/37; Dikr, 21/37). La noticia apunta quizás a una jerarquización de la importancia y prioridad de las actuaciones y encaja en el panorama de discontinuidad de los procesos constructivos que se documenta en estos primeros momentos, marcada por el desconocimiento de las canteras donde obtener piedra, la ausencia de expertos o la desarticulación de las redes de abastecimiento. La reutilización es aquí una necesidad (Gurriarán, 2004, p. 300; Utrero y Sastre, 2012; Caballero y Utrero, 2013, p. 142).

Posteriormente, para la construcción de la mezquita de Córdoba, las canteras ya serían explotadas y se emplearían para la extracción de sillares de la cimentación del edificio. Otros materiales, que no fuesen capiteles, fustes o cimacios, son también reutilizados, pero tienen apenas un valor constructivo. El pedestal de una estatua con una inscripción fue recortado y adaptado como cimacio en la mezquita, con la inscripción en posición invertida (Stylow, 2000). Igualmente, un fragmento de sarcófago romano de temática cristiana fue reutilizado como cimiento de uno de los pilares del oratorio (Fig. 2) (Fontaine, 1947, p. 99; Sotomayor, 1973, pp. 105-106; García García, 2004, pp. 245-246, figs. 3 y 4$)^{5}$.

4 En Jirbat al-Mafyar (Jordania) se documentó la cabeza de una estatua de mármol de Atenea, reutilizada en la construcción de un muro del edificio, algo que resulta significativo puesto que en ese y en otros palacios omeyas semejantes se utilizaba piedra o estuco para elaborar nuevas estatuas. Kristensen, 2013, p. 251. Según B. Finster, 2009, p. 283, abb. 11, varias serían reproducciones de estatuas clásicas.

5 La pieza no era en ningún caso visible, pero lo interesante es que las figuras cristianas han sido rudamente mutiladas con la excepción de dos personajes realizados en bajorrelieve. 
Este panorama que nos ofrece la ciudad de Córdoba puede extenderse a otras regiones de al-Ándalus donde también se documenta una reutilización masiva con fines meramente constructivos, independientemente de que estas construcciones deban asociarse al poder omeya o a poderes locales y tengan o no un componente ideológico. En Sevilla, se reutilizaron columnas y capitales para la edificación de la mezquita de Ibn 'Addabas (Valor, 1993; Cómez, 1994). La más antigua inscripción árabe que conservamos se refiere justamente a la fundación de la mezquita en 829-830 y está realizada sobre una columna romana (Ocaña, 1970, pp. 22-23). En Mérida, los edificios de Morería, bien datados en la segunda mitad del siglo VIII o comienzos del IX, se construyeron con mampostería rematada por tapial y abundante material reutilizado (Alba, 2001 y 2009). El edificio documentado en las inmediaciones del "Templo de Diana", con similares características y cronología, fue construido enteramente con materiales reutilizados (Alba, 2004, pp. 60 y 66) y la alcazaba de Mérida fue erigida en el 835 , reaprovechando toda clase de materiales procedentes del desmantelamiento parcial de la muralla y la destrucción de la puerta romana de la ciudad, decretada por 'Abd al-Raḥmān II (Ibn al-Ațīr, Kāmil, VII, 189/243; Alba, 2001, p. 293; Alba y Feijoo, 2005, p. 103).

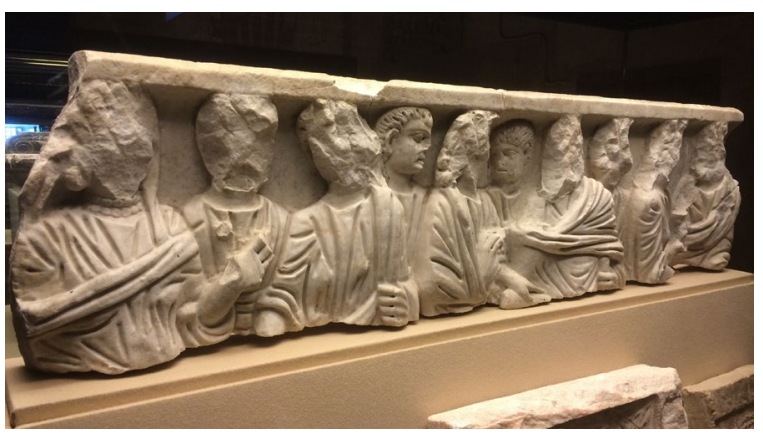

Figura 2. Fragmento de sarcófago romano reutilizado como cimiento en la mezquita de Córdoba (fotografía del autor).

\section{LAS "MARAVILLAS" Y "RUINAS DE LOS ANTIGUOS"}

El uso constructivo y el valor utilitario que se le da a los materiales antiguos es el aspecto más destacado de la reutilización en al-Ándalus, algo que se repite de forma recurrente en los siglos posteriores, sin que esto sea un rasgo exclusivo de la península. Contando pues con esta continuidad, sí creo que cabe destacar un punto de inflexión ya en el siglo IX, que afecta al modo en el que estas antigüedades son percibidas y reutilizadas: supone el paso de unas piezas vistas fundamentalmente como recurso constructivo a ser consideradas propiamente como "maravillas" y "ruinas de los antiguos" ('âyâ'ib wa ātār al-'Awā'il) con un significado o valor histórico por sí mismas, y capaces de evocar un discurso sobre el pasado.

Este cambio resulta evidente en varios aspectos. En primer lugar, se detecta un descenso en la cantidad de material reutilizado si comparamos grosso modo las realidades de los siglos VIII-X. Desde finales del siglo IX y, tras la proclamación del califato de Córdoba por 'Abd al-Raḥmān III en el año 929, no se detecta la presencia masiva de elementos reutilizados en la arquitectura oficial omeya ${ }^{6}$.

En segundo lugar, la reutilización se traslada a piezas singulares, por sus dimensiones, origen, calidad $u$ ornamentación. No se trata de elementos de decoración arquitectónica, sino de otro tipo de piezas: sarcófagos, pilas, inscripciones, estelas o estatuas. Curiosamente, las fuentes árabes sí suelen mencionar ahora las antigüedades, destacando su carácter monumental y decorativo, así como su origen más o menos fantasioso. Además, estos elementos reutilizados parecen quedar reservados a espacios palatinos y a una arquitectura vinculada con el poder. El ejemplo paradigmático es el conjunto de sarcófagos romanos y estatuas reutilizados en Madīnat al-Zahrā', la ciudad palatina de los Omeyas, construida en el siglo X. Me referiré a ello más adelante.

Otro caso similar es el de Samarra, la ciudad fundada por el califa 'abbāsí al-Mu'tașim en 836, donde se ha localizó una pila monumental en granito rojizo egipcio, realizada en un solo bloque de piedra y con una franja ornamental a modo de decoración. Esta pila fue localizada por E. Herzfeld en el "Harim" de la Dār al-Khilāfa, pero habría sido emplazada en el centro del patio de la mezquita de Samarra como pila de abluciones: la pieza presenta dos orificios de desagüe y habría estado conectada con una canalización de agua. Las fuentes árabes aluden a esta pieza con gran atención. Señalan el nombre con el que era conocida, la "Copa de Faraón" (kāsat Fir'ūn), sus extraordinarias dimensiones y su fastuoso traslado desde palacio al-Hārūnī, donde habría estado originalmente ubicada durante el reinado de al-Wāthiq (842-847),

6 La estandarización de los aparejos en sillería alternando los bloques a soga y tizón constituyen un referente de la arquitectura denominada como "oficial" del estado omeya. Su primera aparición destacada sería en la mezquita de Córdoba. Este tipo de aparejo se va imponiendo en las grandes construcciones, dentro y fuera de Córdoba, aunque los aparejos mixtos, reutilizando materiales, continúan: Gurriarán, 2004; Azuar, 2005; Caballero y Utrero, 2013; León-Muñoz, 2018, p. 9. 


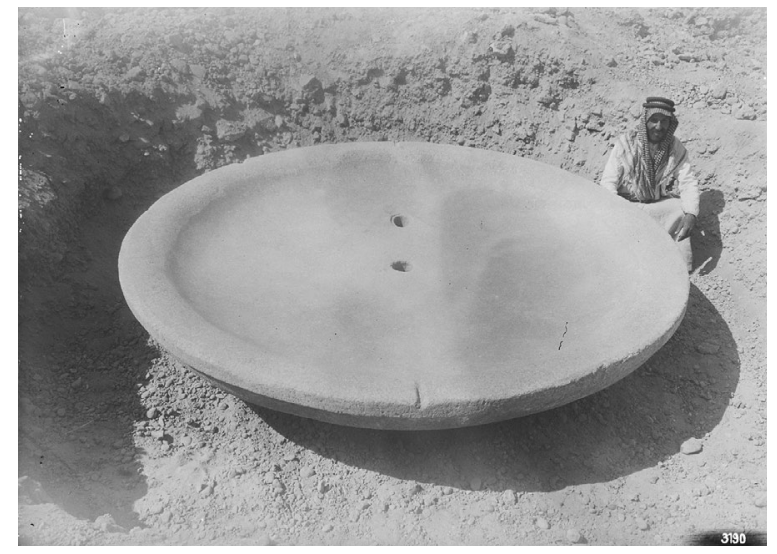

Figura 3. Pila hallada en el Palacio califal de Samarra por E. Herzfeld (FSA A.6 04.GN.3190, cortesía de Smithsonian Institution).

hasta la mezquita, recurriendo para ello a tres elefantes (Figs. 3 y 4) (Ibn al-Jawzī, Al-Muntazam, XI, p. 252 y trad. Northedge, 2008, pp. 122-123; Al-Qazwīnī, Nuzhat-al-qulub, trad. Le Strange, 1917, p. 42; Northedge, 2008, p. 123).

En tercer lugar, la apropiación de estas antigüedades por parte del poder debe entenderse como deseo de controlar todos los aspectos vinculados con estas: desde la búsqueda de piezas, hasta su selección, almacenamiento y reutilización final. Evidencias de ello las encontramos en el contexto de las conquistas islámicas. En Egipto, las autoridades regularon la búsqueda y el destino final de los hallazgos durante el gobierno de 'Amr b. al-'Āṣ y al parecer varias estatuillas fueron enviadas al califa 'Umar II (r. 717-720) (Al-Maqrīzī, al-Jitat, I, p. 110; El Daly, 2005, pp. 41-42). Ya en el siglo IX y X este control parece plenamente establecido: nadie podría excavar sin el permiso previo de las autoridades y al frente del sistema figuran el amīr al-mațalibīn (jefe de los buscadores) y el naqīb al-matalibin (encargado de los buscadores) (El Daly, 2005, pp. 34-42).

En al-Ándalus también cabe señalar algo parecido. Según una noticia, el emir 'Abd al-Raḥmān II rebuscaba en todas las comarcas en busca de columnas e instrumentos de toda clase, reuniéndolos y llevándolos al alcázar de Córdoba (Ibn Hayyān, Muqtabis, II-I, p. 143v). Prueba de ello serían las columnas y capiteles emeritenses reutilizados en la mezquita de Córdoba, como señalaba anteriormente. El sistema podría sustentarse en los gobernadores locales, como atestigua otra referencia en la que un gobernador de Mérida, 'Abd Allāh b. Kulayb b. Ta'laba, general de 'Abd al-Rạ̣mān II, procuraba mármoles en la ciudad

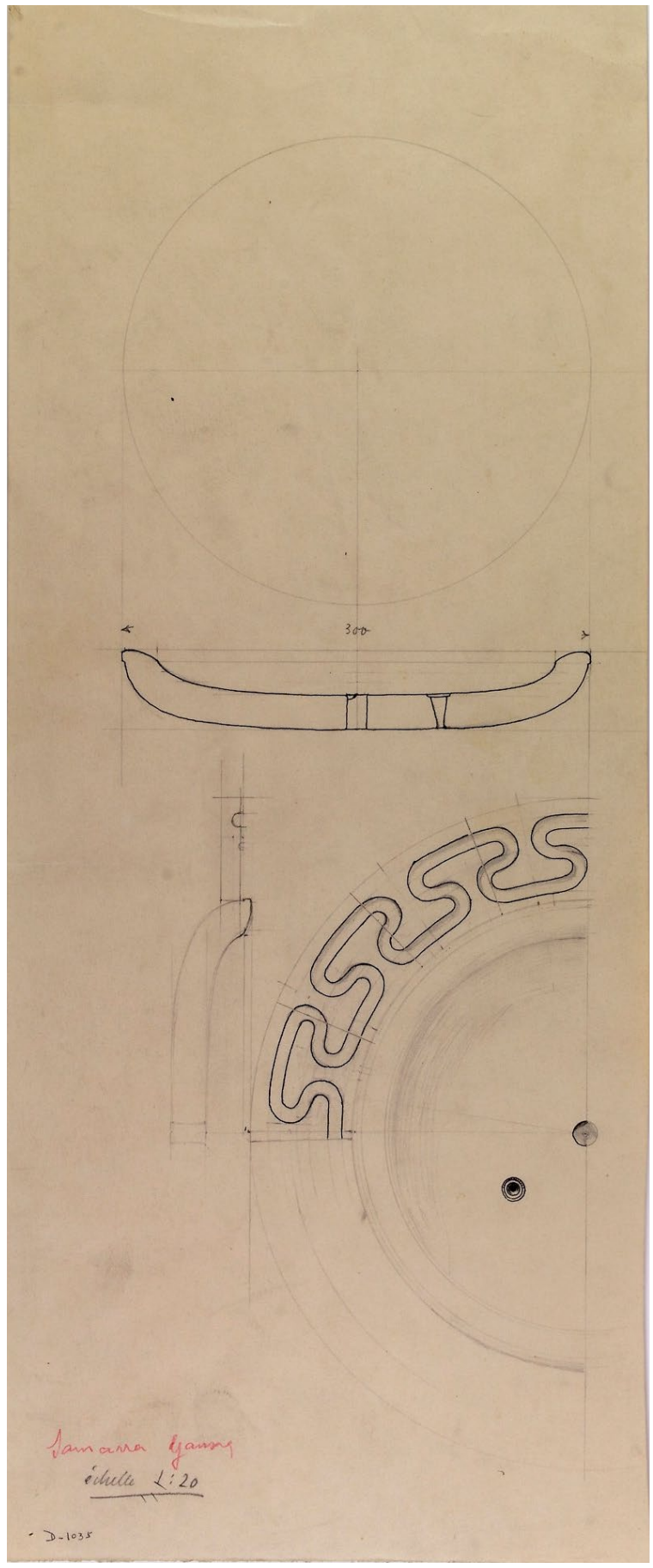

Figura 4. Detalle de la decoración de la pila: planta y sección (FSA A.06 05.1035, cortesía de Smithsonian Institution).

y pedía que se los trajeran para llevárselos. En una ocasión habría hallado una fabulosa inscripción latina (Al-Rušātịi, Iqtibās, texto árabe y trad. en Torres Calzada, 2014, pp. 255-256 y 243-244; Rasis, pp. 7276). Este sistema tendría su centro en el Alcázar de 
Córdoba como el lugar donde estas piezas quedaban almacenadas, a la espera de ser reutilizadas. Ello explicaría también la rápida construcción de la mezquita. Además, parece que algunas piezas quedarían expuestas, según se desprende de algunas noticias que aluden a pilas o sarcófagos reutilizados como fuentes de agua (Ibn Hayyān, Muqtabis, II-I, p. 140r-v; Al-Maqqarī, Nafh, I, p. 464, trad. en Rubiera, 1981, p. 122), o la mención a una enigmática Casa del Mármol (Dār alruḥām) (Ibn Hayyān, Muqtabis VII, trad. García Gómez, 1967, p. 334) ${ }^{7}$.

Finalmente, un cuarto aspecto que denota este cambio en la percepción y reutilización de antigüedades se refiere a la procedencia de estos materiales. Ya no parecen provenir del expolio de edificios, iglesias o palacios, sino del desmantelamiento de estructuras preislámicas, algunas de ellas en uso hasta la fecha, de nuevos hallazgos que se suceden al excavar la tierra y de los que dan buena cuenta las fuentes escritas ${ }^{8}$, así como de los cementerios, donde es de suponer que actuarían estos saqueadores (Greenhalgh, 2009, p. 221).

\section{UNA FETUA COMO FUENTE PARA ENTENDER EL CAMBIO}

A este último aspecto se refieren una serie de fetuas, es decir, consultas jurídicas realizadas por ulemas o alfaquíes acerca de cuestiones que precisan de una aclaración en el derecho islámico. Son, por tanto, una fuente a tener en cuenta para entender el fenómeno de la reutilización. En este sentido, algunos estudios han ahondado en esta perspectiva en relación al Norte de África, denotando que la reutilización era una actividad habitual, que generaba pingües beneficios, y precisaba ser regulada, atendiendo a la propiedad, el origen y el destino de las piezas (Mahfoudh, 2011, pp. 62 y 64).

En el caso de al-Ándalus, al-Wanšarīsī (m. 914/1508) recoge una serie de fetuas referidas a los siglos IX y X que insisten en la necesidad de reglamentar el origen de los materiales que se van a emplear en nuevas construcciones, especialmente en lo que se refiere a la edificación de mezquitas (Al-Wanšarīsī, al-Miyār, VII, pp. 66, 138, 143 y 153-154) ${ }^{9}$. Una fetua

7 La mención aparece referida al paso de revista de las tropas por el califa al-Hakam II y en este sentido es interpretado como un distrito militar dentro del alcázar por Montejo y Garriguet, 1998: 305.

8 En este sentido una referencia enigmática sería el hallazgo de una estatua en Itálica y que fue trasladada a Sevilla: Al-Bakrī, K. al-Masālik, 1517/1534.

9 Acerca este autor y esta importante obra: Vidal Castro, 1993 y 1995; Lagardère, 1995. emitida por el cadí cordobés Ibn Lubāba (m. 314/926) se muestra desfavorable a que se reutilicen piezas y materiales de los cementerios abandonados para la construcción de puentes o mezquitas (Al-Wanšarīsī, al-Miyār, VII, p. 103 y una noticia muy similar en VII, pp. 456-457; Lagardère, 1995, pp. 254 y 291).

La noticia no señala que se trate de cementerios preislámicos, pero no parece descabellado pensarlo. La fetua haría pues mención al rechazo de antigüedades y elementos correspondientes al mundo pagano de la ŷāhiliyya y a la necesidad de regular la reutilización de estos objetos en edificaciones de carácter sagrado, como las mezquitas, o público, como los puentes. Descartado este destino, los hallazgos se reutilizarían quizás en otras construcciones. En Córdoba se localizó un fragmento de un sarcófago cristiano tardorromano reutilizado como umbral de una puerta de una casa musulmana en Córdoba y al que se le ha practicado un agujero para encajar un gozne. La particularidad es que la pieza está colocada con la decoración figurada hacia arriba cuando lo práctico habría sido al revés, para aprovechar la superficie lisa (Fig. 5) ${ }^{10}$.

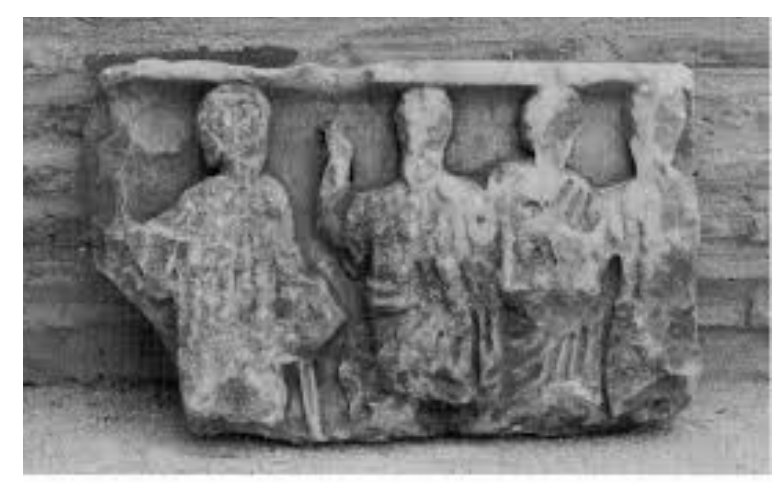

Figura 5. Fragmento de sarcófago cristiano (Sotomayor, 2000, p. 276).

Sin desconsiderar esta interpretación tradicional, creo, sin embargo, que se podría ir más allá: esta fetua indicaría el cambio en la percepción y reutilización de antigüedades que he señalado anteriormente. Varios aspectos apuntan en este sentido.

La construcción de puentes y mezquitas en Córdoba es una iniciativa que corresponde generalmente a

10 No se precisa la cronología de la casa musulmana, pero R. Hidalgo, 2001, p. 248 la vincula al arrabal de época califal construido en las inmediaciones del complejo de Cercadilla. Sobre la escena eliminada: Sotomayor, 2000, pp. 280-281. También García García, 2004, pp. 246-247, figs. 5 y 6; Calvo Capilla, 2012, p. 148. 
los Omeyas y a su círculo más próximo, y está asociada directamente a la configuración del espacio urbano y la islamización de la población en época emiral y califal (Acién y Vallejo, 1998, p. 114 y ss.). Sin embargo, no parece que a finales del siglo IX y comienzos del $\mathrm{X}$ se llevaran a cabo grandes edificaciones en Córdoba recurriendo para ello a material reutilizado $\mathrm{y}$, mucho menos, procedentes de cementerios. Desde finales del siglo VIII parece haber evidencias de la explotación de las canteras, que se utilizaron para obtener sillares con los que realizar la cimentación de la mezquita de Córdoba. Tan solo una noticia relativa al saqueo de Narbona en 177/793 alude a los "materiales obtenidos de la demolición de sus muros" (seguramente mármol), que quedaron almacenados enfrente del alcázar omeya en Córdoba y posteriormente se emplearon para construir una nueva mezquita en Córdoba y para reparar el puente (Ibn al-Qūțiyya, Ta'rīj, p. 43/33-34; Fath, p. 46/37) ${ }^{11}$. Sin embargo, a comienzos del siglo $\mathrm{X}$, la explotación de las canteras es sistemática, justamente para abastecer las construcciones que se realizan en ese momento (León Muñoz, 2018, p. 9).

Las mezquitas de Córdoba han sido bien estudiadas por C. González Gutiérrez y no se detecta que exista una reutilización destacada de material procedente de cementerios $^{12}$. En el alminar de la actual iglesia de San Juan, construido justamente a finales del siglo IX o inicios del siglo $X$, se emplearon sillares tallados en piedra caliza, dispuestos a soga y tizón, aunque de forma irregular (González Gutiérrez, 2015, pp. 161-162 y 288-290). Los ejemplos de reutilización se refieren a piezas muy concretas, por ejemplo, en la mezquita de la estación de Autobuses, de inicios de época califal, se ha podido documentar un ara destinada a reforzar la esquina NE de la quibla (Castro, 2005, pp. 58-59; González Gutiérrez, 2015, pp. 127-128) $)^{13}$. En el caso de los puentes contamos con menos evidencias al respecto. Todo apunta a que para su construcción se emplearían sillares procedentes de cantera y quizás en algunos casos quepa apuntar la existencia previa de puentes romanos reaprovechados (Bermúdez Cano, 1993, pp. 277-283).

11 La noticia refuerza la hipótesis, ya planteada anteriormente, de que el Alcázar omeya hiciera las veces de almacén y colección de materiales y piezas antiguas notables.

12 Para la edificación de estas mezquitas cordobesas se emplearían columnas, reaprovechadas o talladas a imitación de estas. González Gutiérrez, 2012, p. 212; 2015, pp. 112, 198 y 245.

13 En la mezquita califal de El Fontanar, en el sector occidental suburbano de Córdoba, ubicada sobre un antiguo cementerio tardorromano, no parece que se reutilizaran materiales provenientes de áreas funerarias, aunque la mezquita sufrió un fuerte expolio a posteriori: Luna y Zamorano, 1999, p. 146.
Sabemos también que el califa al-Hakam II acometió una nueva reconstrucción del puente y la ampliación de la mezquita aljama. Para ambos casos se emplearía material nuevo, procedente de canteras. Además una noticia alude a la existencia de un "zoco de las piedras" (sūq al-șujūr) en el siglo X, al que habría acudido Ŷa'far al-Șaqlabī para buscar materiales con los que construir la ampliación de la mezquita (Ibn 'Idārī, Bayān, II, p. 233). La noticia refleja la plena organización de este sistema y la regulación tanto del origen lícito de las piezas como del control mercantil y fiscal por parte de la autoridad. Es a este marco regulado al que se recurre en busca de los materiales con los que construir la mezquita en el siglo $\mathrm{X}^{14}$.

De este modo, la fetua centra su atención en regular el origen del material reutilizado en puentes y mezquitas, sin embargo, a comienzos del siglo $\mathrm{X}$, la actividad constructiva se sustentaba principalmente en la explotación de canteras y no parece haber una reutilización de piezas procedentes de cementerios en estas edificaciones. Por tanto, quizás la fetua no atendía a la necesidad de regular el destino de las piezas, sino el origen de las mismas, es decir, los cementerios. ¿Por qué a comienzos del siglo $\mathrm{X}$ era importante regular estos hallazgos? En mi opinión, estamos ante la imposición del control sobre los materiales por parte de la autoridad que se estaba produciendo a finales del siglo IX y comienzos del siglo $\mathrm{X}$ y al que me refería anteriormente. El momento coincide justamente con el fuerte crecimiento urbano de Córdoba, ocupando los sectores suburbanos occidentales donde se encontraban algunos cementerios preislámicos en torno al complejo de Cercadilla, el anfiteatro romano y el Cortijo de Chinales (Fig. 6) (Vaquerizo y Murillo, 2010, II, pp. 540-547; Manzano, 2019, p. 319) ${ }^{15}$.

La fetua ahonda además en la idea de la reutilización como un recurso constructivo, pero, dado que esto desentona con la realidad del momento (apenas se reutilizaban piezas procedentes de cementerios en mezquitas y puentes), quizás la fetua nos está ocul-

14 Paralelos a esta situación se documentan en el Norte de África donde un fuste de columna en la mezquita de Qayrawān contiene la inscripción "para la mezquita" (Mahfoudh, 2011, p. 63).

15 Acerca de las necrópolis preislámicas de Córdoba: Sánchez Ramos, 2010; Vaquerizo y Murillo, 2010, II, pp. 547-561. Las estructuras preislámicas construidas sobre el anfiteatro romano, vinculadas con un espacio de culto cristiano de carácter martirial, fueron sometidas a un intenso saqueo durante el siglo IX y especialmente el $\mathrm{X}$, abriendo fosas para la extracción de material constructivo: Vaquerizo y Murillo, 2010, II, pp. 513518 ; León-Muñoz, 2018, p. 5 y nota 6. En el sector de Cercadilla y de la actual estación de autobuses se documentó también la existencia de un oratorio de época califal. Acerca de estas mezquitas de barrio: González Gutiérrez, 2016. 


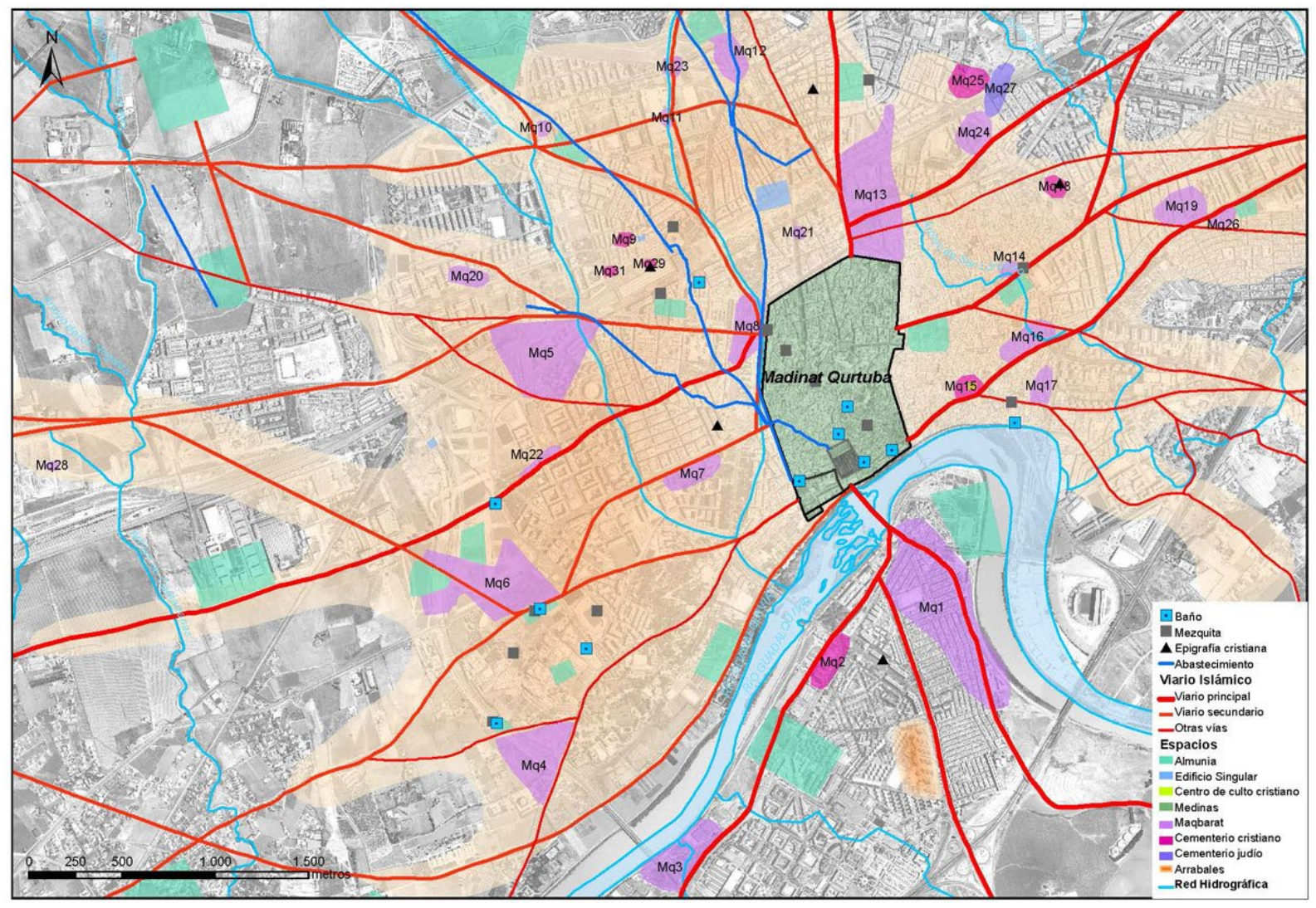

Figura 6. Aglomeración urbana de Córdoba en época califal, siglo X (Convenio GMU-UCO).

tando una nueva valoración de los materiales distinta y más cercana a la concepción de "maravillas" y "ruinas de los antiguos". En última instancia la fetua debe relacionarse con en el fabuloso conjunto de sarcófagos (lisos y figurados) y estatuas reutilizadas en la ciudad palatina de Madīnat al-Zahrā', la nueva capital del califato. Parece pues que las piezas encontradas por entonces en los cementerios no eran simples materiales constructivos, sino sarcófagos y esculturas que acabaron siendo parte esencial de la nueva ciudad califal. Su construcción comienza en 936, apenas a unos kilómetros al oeste de Córdoba, y se prolonga durante varias décadas. A. Vallejo ya había señalado como la hipótesis más factible que estos sarcófagos deberían proceder de las necrópolis occidentales de Corduba (Vallejo, 2010, p. 238, nota 37) ${ }^{16}$. Esta fetua secun-

16 A. García y Bellido, 1959 aludía al hallazgo de un sarcófago romano con el tema de la "Puerta del Hades" en la Huerta de San Rafael, emplazado en la actualidad en el Alcázar de Córdoba. En la zona habría pues una necrópolis. Es netamente similar a otro sarcófago documentado en Madīnat al-Zahrā'. daría esta idea e ilustra acerca del cambio operado en al-Ándalus en el uso y significado otorgado a las antigüedades a comienzos del siglo $\mathrm{X}$, ahondando en el control de los hallazgos y su consideración como "maravillas de los antiguos". Sobre este último aspecto es sobre el que voy a incidir a continuación.

\section{LA COLECCIÓN DE ANTIGÜEDADES DE MADİNAT AL-ZAHR $\bar{A}$,}

Al contrario que en caso anteriores, en Madinat al-Zahrā' no se recurre a capiteles o columnas, sino a elementos figurados, estatuas y sarcófagos excepcionales en el contexto hispánico, cuya reutilización no atiende a criterios constructivos, sino fundamentalmente estéticos, como veremos. Constituye también un ejemplo único. No he podido documentar casos similares de reutilización en el resto del mundo medieval, islámico o cristiano. Los ejemplos de reutilización en el califato 'abbāsí se reducen a los ejemplos ya mencionados en Samarra. En el caso del califato fătimí, surgido en el Norte de África a comienzos del siglo IX como una dinastía rival a la de los Omeyas, 
parece que la reutilización se refiere fundamentalmente a capiteles, columnas y basas (Cressier y Rammah, 2006; Cressier, en prensa). En los reinos cristianos, los sarcófagos romanos fueron reutilizados como lugar de enterramiento ciertamente prestigioso. Es el caso del sepulcro de Fernán González y su esposa Sancha de Pamplona (Moráis Morán, 2017).

Además, este conjunto de antigüedades de Madīnat al-Zahrā' debe ponerse en relación con la ciudad palatina de los Omeyas y con el proyecto de legitimación de los califas. Este proyecto destaca por un inusitado interés por el pasado preislámico durante el siglo X que busca explicar la realidad presente y legitimar el poder y la autoridad de la dinastía. Los autores andalusíes acudieron a las fuentes clásicas para relatar diversos episodios de la historia universal y peninsular, de tal manera que las referencias a la tradición coránica compuesta por profetas, reyes y adalides del islam conviven con noticias sobre Hércules, Viriato, Julio César, Augusto, Constantino o Leovigildo. Hay dos obras que reflejan este cambio y aparecen en el seno de la ciudad de Córdoba durante la primera mitad del siglo X: la traducción árabe de Adversus paganos historiarum libri septem, de Paulo Orosio (m. 410 d. C.), conocida como el Kitāb Hurūšiyūs y el Ta'rīj fi ajbār mulūk al-Andalus de Aḥmad al-Rāzī (m. 955) ${ }^{17}$.

El conjunto de antigüedades de Madīnat al-Zahrā , ha sido relativamente estudiado. J. Beltrán y posteriormente A. Vallejo y S. Calvo han profundizado en el estudio de los sarcófagos, su tipología, características, reutilización y propósito (Beltrán Fortes, 1988-1990 y 1999; Beltrán Fortes, García García y Rodríguez Oliva, 2006; Vallejo, 2010; Calvo Capilla, 2012, 2013 y 2014). La cifra de sarcófagos alcanza actualmente los veinticinco, de los cuales, los sarcófagos figurados, datados entre mediados y segundo cuarto del siglo III d. C., ocupan por sus dimensiones y calidad un primer plano (Beltrán, 1989-1990; Vallejo, 2010, p. 236). En cambio, el conjunto de estatuas es más reducido: un busto fue encontrado en el patio anexo a la Dār al-ŷund(Beltrán 1988-1990, p. 113), un herma que representa a Hércules-niño (Beltrán, 1988-1990, p. 112 , lam. I-1; 1993) y la cabeza de un retrato femenino datado en el siglo III, procedente de la explanada frontera al Pórtico (Figs. 7-11) (Beltrán, 1988-1990, pp. 112-113 y lam. I-2; Vallejo, 2010, pp. 262-263, fig. 208). Su origen, a diferencia de los sarcófagos, no está claro, pero por sus dimensiones y heterogeneidad, se asemejan a las colecciones de escultura de las villas

17 Varios estudios se han centrado en estas dos obras: Rasis, 1975; Molina, 1982-1983; Kitāb Hurūšiyūs, introd. Penelas; Elices y Manzano, 2019; Elices, 2020, pp. 90-112 tardorromanas, por lo que quizás cabría pensar que fueran recuperadas de algunos de estos enclaves en el entorno del Valle del Guadalquivirir ${ }^{18}$.

El principal problema a la hora de abordar este conjunto es el estado en el que se encontraron las piezas: están fragmentadas, descontextualizadas, y fueron destruidas, coincidiendo con el final del Califato a comienzos del siglo XI o quizás durante el periodo almohade (Beltrán, 1988-1990, p. 111; Vallejo, 2010, p. 262). Solo dos sarcófagos («Meleagro y la caza del jabalí de Calidón» y la «Puerta del Hades») han sido reconstituidos (Beltrán, 1988-1990, p. 113 y ss., 1999, pp. 112-166). Pese a ello ha sido posible determinar la funcionalidad que tuvieron estos sarcófagos (nada se ha apuntado con respecto a las estatuas).

La tesis más difundida es la de que fueron empleados como pilas de agua (Beltrán, 1988-1990, p. 110; Vallejo, 2010, p. 236). La clave de esta interpretación reside en las intervenciones que sufrieron los sarcófagos: han sido pulidos, restaurados parcialmente con estuco y presentan orificios en los laterales (Calvo Capilla, 2012, p. 145 y fig. 7 y 2014, p. 8) ${ }^{19}$. Por ejemplo, el sarcófago de «Meleagro y la caza del jabalí de Calidón» tiene dos perforaciones que coinciden con los dos orificios existentes en la tapa de la alcantarilla del Patio de los Pilares. Esto ha permitido conocer su ubicación exacta en el centro del patio (Vallejo, 2010, p. 237). Las fuentes árabes secundan además esta idea. Ya he mencionado anteriormente que en el Alcázar de Córdoba existían sarcófagos y pilas de mármol con esta misma función de fuentes de agua y también contamos con noticias que aluden al mismo contexto en Madīnat al-Zahrā' (Al-Maqqarī, Nafh, I, p. 566; Rubiera, 1981, pp. 30 y 36-37).

¿Cuál fue el propósito y el significado dado a este conjunto de antigüedades? ¿Cabe pensar solo en un valor decorativo y en una reutilización como fuentes y pilones de agua, es decir, eminentemente ornamental? Sin contradecir este aspecto que resulta evidente, distintos investigadores han tratado de ir más allá y ofrecer una explicación más completa, no en vano, se trata de un conjunto de antigüedades realmente significativo. De este modo, S. Moralejo y J. Beltrán apuntaban a un "gusto anticuario", es decir, al aprecio de las pie-

18 M. Greenhalgh ha sugerido precisamente que las columnas reutilizadas en la mezquita de Córdoba proviniesen también de algunas de las villas del Valle del Guadalquivir (Greenhalgh, 2009 , p. 177). Ya en el siglo XI una estatua hallada en Itálica fue trasladada a Sevilla: Al-Bakrī, K. al-Masālik, 1517/1534.

19 En algún caso concreto se ha podido documentar el sistema de alimentación, con una pieza rectangular de mármol que se encuentra parcialmente vaciada para engastar en ella una tubería de plomo: Vallejo, 2010, p. 242, nota 47 y lám. 193. 


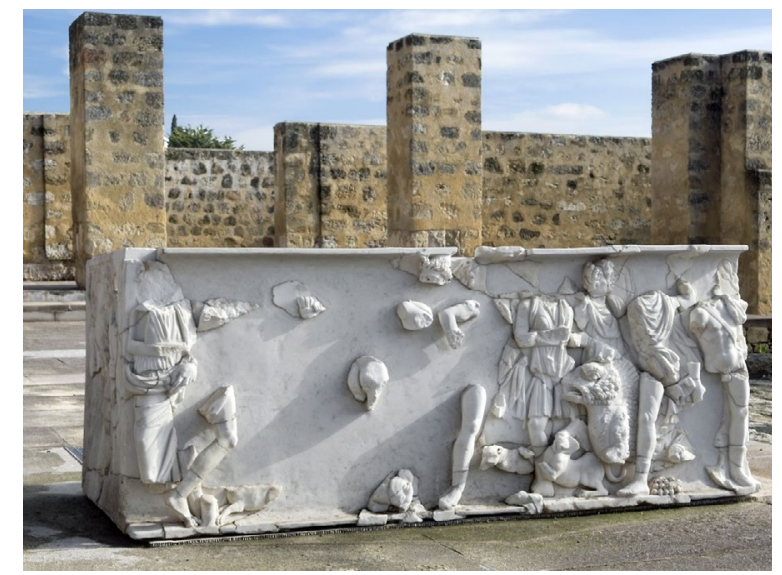

Figura 7. Sarcófago de Meleagro y la caza del jabalí de Calidón (imagen cortesía de Conjunto Arqueológico Madinnat al-Zahrā'/ Junta de Andalucía).

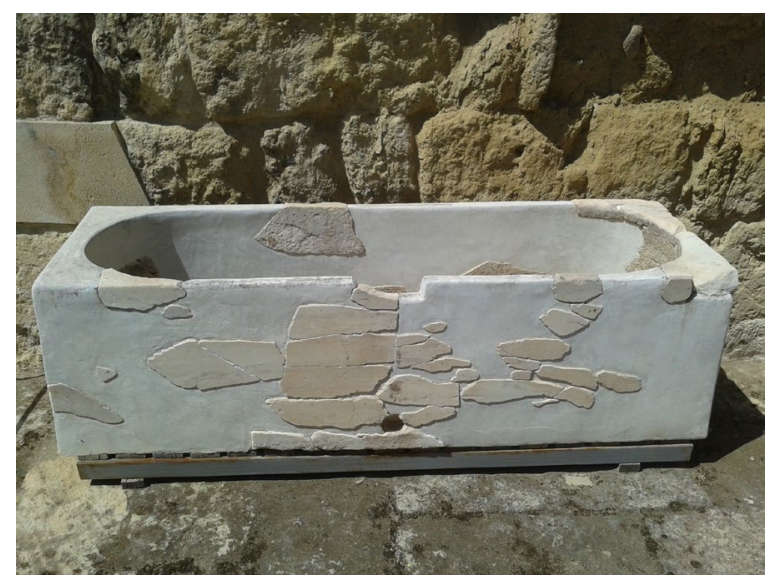

Figura 8. Sarcófago de mármol de las Caballerizas en Madīnat alZahrā' (fotografía del autor).

zas por su belleza y antigüedad (Moralejo, 1982, p. 188; Beltrán, 1988-1989, p. 109). Más recientemente, S. Calvo Capilla ha relacionado los sarcófagos con determinados espacios consagrados al saber (biblioteca, educación de los príncipes, astronomía), donde serían considerados como "alegorías del Saber de los Antiguos" y "una referencia visual a la antigüedad clásica" (Calvo Capilla, 2012, p. 148 y ss.; 2013 y 2014, p. 25).

Esta hipótesis, pese a ser ciertamente sugestiva, obvia la amplia distribución de antigüedades a lo largo de toda la ciudad palatina, tanto estancias privadas como públicas y de uso administrativo, tal y como ha atestiguado A. Vallejo (Vallejo, 2010, pp. 262-263 y en prensa). Además, las características de la recepción omeya de la antigüedad esconden un amplio abanico de actitudes y respuestas, frecuentemente contradictorias, que deben ser también consideradas (Elices y Manzano, 2019; Elices, 2020, pp. 163-214). Diría pues que esta
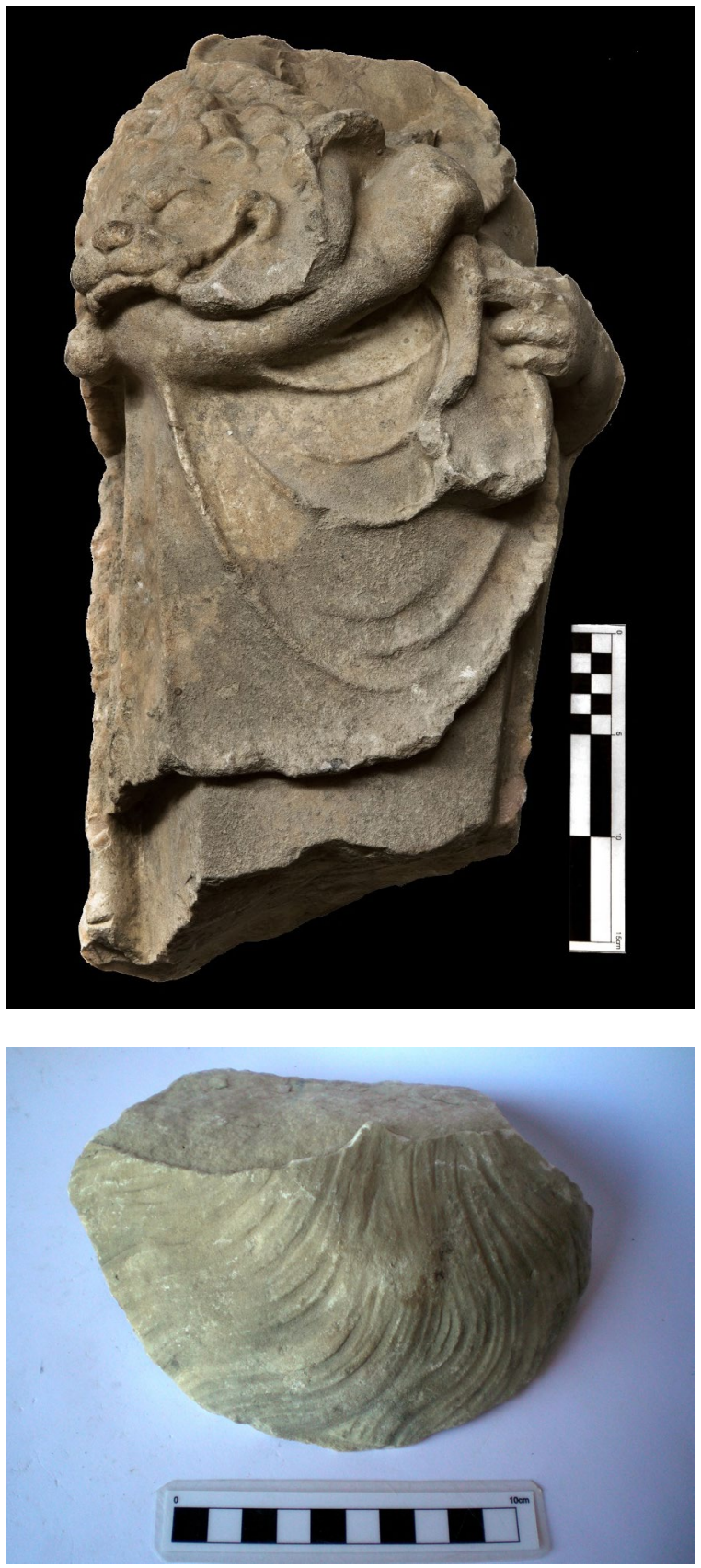

Figuras 9 y 10. Herma de Hércules-niño y fragmento de una cabeza masculina (imágenes cortesía de Conjunto Arqueológico Madinat al-Zahrā'/Junta de Andalucía).

hipótesis simplifica la variedad de significados que suscitaron estas antigüedades. El conjunto de Madinnat alZahrā'refleja la madurez de los procesos de búsqueda, selección, acopio de antigüedades durante el califato, y como he señalado, el propósito de esta colección debe ponerse en relación con la legitimación omeya y el control de las "maravillas" halladas y su apropiación por 


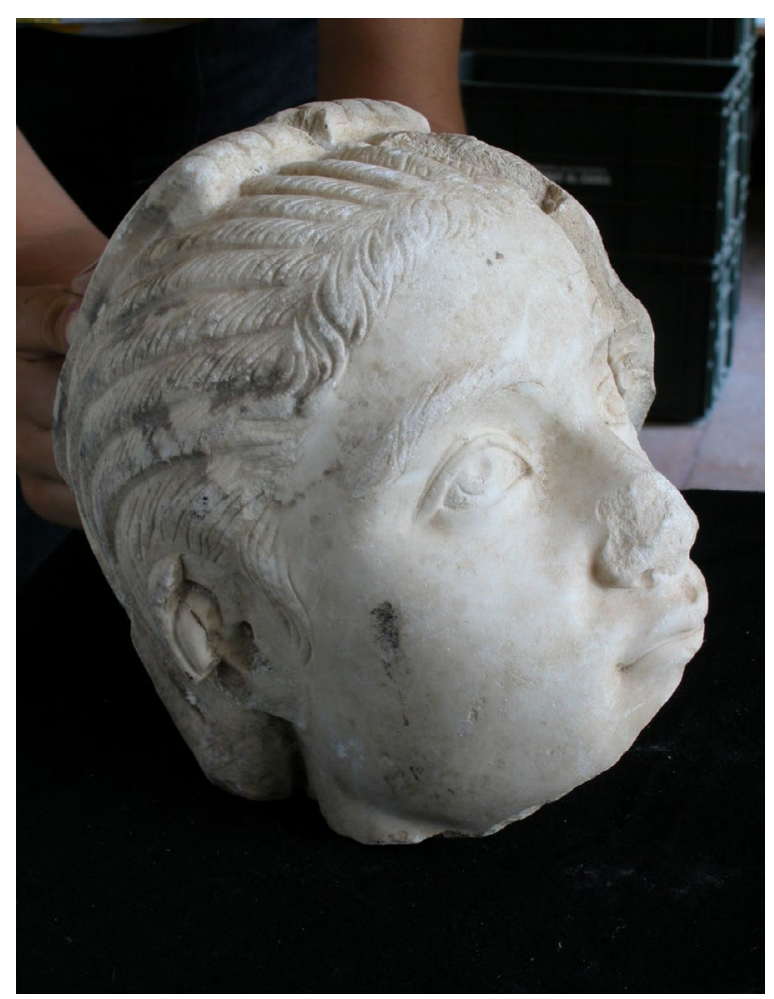

Figura 11. Cabeza femenina procedente de la explanada frontera al Pórtico (imagen cortesía de Conjunto Arqueológico Madīnat al-Zahrā'/Junta de Andalucía).

parte de los califas. La colección de antigüedades de Madīnat al-Zahrā' ilustra también el cambio de mentalidad a la hora de considerar la cultura material de un "otro", no como elementos extraños, paganos o bárbaros, sino como objetos propios, valiosos y coleccionables más allá de su utilidad como recurso material. En mi opinión es necesario insistir en término «anticuario»" entendido aquí como la valoración y recuperación de antigüedades, motivada tanto por una curiosidad como por un deseo de conocimiento, centrado en determinar el origen, procedencia y sentido que debieron tener estos objetos, así como una voluntad de hacer acopio de ellos, coleccionarlos y preservarlos, dándoles un propósito y significado en el presente (Schnapp, 2007, 2013).

Considero también que estas antigüedades debieron tener un significado propio e individualizado en el que convergen elementos tanto de la tradición clásica como islámica (relatos históricos, literarios, memorias e identidades). Recordemos el caso de la fastuosa pila de granito empleada como fuente en Samarra y conocida como la "Copa del Faraón". En este sentido cabe considerar también las ideas apuntadas por W. Shaw que sostiene que el material reutilizado suele tener propósitos narrativos y didácticos comparables, pero obviamente muy distintos ideológicamente, a los que se contemplan en los museos (Shaw, 2003, pp. 38-39). Casos similares de reutilización, reubicación y resignificación de estatuas paganas en un contexto cristiano tardo antiguo sugieren que las piezas figuradas tuvieron también un valor discursivo (Kristensen, 2013, pp. 232-248; Jacobs, 2020). Partiendo pues desde este punto de vista, los sarcófagos y estatuas reutilizados en Madīnat al-Zahrā' fueron sin duda un recurso material y decorativo, pero muy probablemente fueron también piezas con un valor discursivo y un significado propio, es decir, eran el centro de relatos que aunaban diferentes tradiciones y memorias propias del mundo islámico y eran capaces de evocar una reflexión acerca del paso del tiempo, la sabiduría de los antiguos, la banalidad de las cosas temporales, lo eterno y lo perecedero, lo virtuoso o lo criticable, y las advertencias del pasado de cara al presente $\mathrm{y}$ al futuro.

Las fuentes árabes evidencian este tipo de valor discursivo otorgado a las antigüedades. Especialmente interesante es la noticia ya mencionada que aludía el envío al califa 'Umar II (99-101/717-720) de varias de las antigüedades halladas en Egipto. Al parecer, el califa solía mostrar esta colección de objetos a sus visitantes, explicándoles que estas estatuas serían en realidad humanos que habían sido petrificados como castigo divino al faraón de Moisés, siguiendo la interpretación coránica de este pasaje (Al-Maqrīzī, al-Jițat, I, p. 110; El Daly, 2005, pp. 41-42). En al-Ándalus las fuentes también apuntan a una concepción similar de las antigüedades. Sobre Cádiz se señala que "hay restos maravillosos y antiguos que no han sido alterados por el paso del tiempo y que dan testimonio de poderío y de la existencia de un gran reino" (Dikr, 65-66/72) y de Mérida se indicaba que la ciudad conservaba restos aun visibles de edificios que atestiguan la grandeza, el poder y la gloria de sus constructores (Al-Himyarī, Rawd, 518/211). En Játiva, una estatua era calificada de "maravilla sorprendente" ( 'âyâ'ib), obra admirable y vestigio (ātârr) atribuido a los romanos (rūm). Al mismo tiempo, sin que eso suponga una contradicción, era considerada un ídolo (șanam), vinculado a la ȳāhiliyya, y no obstante, tenía la capacidad de evocar una enseñanza sobre el pasado, de tal manera que podría relatar las historias de 'Ad e Iram, dos pueblos míticos de la tradición bíblica y coránica, de tal manera que la estatua resulta más elocuente y exhortadora que Quss b. Sa'ida, un personaje coránico célebre por su sabiduría (Al-Maqqarī, Nafh, IV, p. 116; Ibn al-Abbār, Takmila, I, p. 356, n 1268 , trad. Labarta, Barceló y Veglison, 2011, pp. 78-79, $\left.\mathrm{n}^{\mathrm{o}} 43\right)^{20}$.

20 Estas menciones aparecen recogidas en un poema de Abū 'Āmir al-Burriyān̄i (m. 533/1138-9). 
Los sarcófagos y estatuas de Madīnat al-Zahrā', transmitieron también seguramente un discurso similar a este. Lo más relevante, sin embargo, es que este discurso no se referiría tanto al pasado, como al presente, y no aludiría a los Antiguos, como apuntaba S. Calvo Capilla, sino a los Modernos, a los Omeyas, al islam y a al-Ándalus. Como parte del escenario construido en la ciudad palatina y del proyecto de legitimación de los Omeyas, cabe pensar que estas antigüedades eran elementos que servían para definirse no solo a sí mismos, como dinastía y califas, como soberanos islámicos, ortodoxos, justos y píos, sino también para dar sentido a la realidad de al-Ándalus y del dominio omeya.

El conjunto de Madīnat al-Zahrā' puede ser considerado entonces como un primitivo "gabinete de maravillas", otro concepto asociado habitualmente a los primeros anticuarios europeos, pero que encaja bien con los términos ' $a \hat{y} \bar{a}$ ' $i b$ o garā'ib con los que se designa precisamente a las "maravillas" y "curiosidades", muchas de las cuáles son antigüedades y monumentos preislámicos ${ }^{21}$. Justifico su uso porque la idea aparece reflejada en las fuentes: se alude a pilones (hiyād) reutilizados como fuentes de agua y a las "maravillosas estatuas de figuras humanas (tamātil 'ajībat al-asjūṣ) que ni siquiera la imaginación podría explicar" (Al-Maqqarī, Nafh, I, p. 566; Puerta Vílchez, 2004, p. 8). Las antigüedades de Madīnat al-Zahrā', serían así una muestra del prestigio y la autoridad del dueño de la colección que de alguna forma queda identificado con las características que se asocian a las piezas que había conseguido acumular (singularidad, riqueza, educación, etc.), de forma no muy diferente a como sucedía en las colecciones tardoantiguas de aristócratas y emperadores (Stirling, 2015, p. 144). Este propósito también aparece señalado en las fuentes: estas antigüedades forman parte de un conjunto destinado a provocar el deslumbramiento (bahr) y estupor (raw) de los visitantes al "contemplar el esplendor de la monarquía (bahjat al-mulk) y la grandiosidad del poder (fajāmat al-sultān)" (Al-Maqqarī, Nafh: I, 566; Puerta Vílchez, 2004, pp. 8 y 11-12).

Junto con este discurso universal, legible tanto para propios como extraños, el conjunto de Madīnat al-Zahrā' transmitiría también un discurso más particular y complejo que ahonda en la tradición islámica. La noticia referente a la colección del califa 'Umar II apunta a que las piezas podrían haber suscitado una interpretación coránica en base a un episodio relativo a la ŷāhiliyya que permitía además trazar un discurso que diferenciaba entre obediencia y castigo divi-

21 Acerca de estos dos conceptos (' $a \hat{y} \bar{a}$ 'ib y garā'ib) y su mención en al-Ándalus: Hernández, 1996, pp. 14 y 249-255. no, creyentes y no creyentes, o monarcas tiránicos y soberanos o profetas píos y justos. Desde este punto de vista, las estatuas eran ejemplos y advertencias en piedra, vinculados con ciertas memorias e identidades propias de la comunidad islámica. De modo significativo, la idea reaparece de nuevo en Madīnat al-Zahrā'. Aludiendo precisamente a los sarcófagos y estatuas, se señala lo siguiente:

loado sea Quien ha facultado a esta débil criatura [el ser humano] para crear e inventar todo eso con fragmentos de esta tierra abocados a la descomposición, con la intención de hacer ver a los siervos que Le ignoran un ejemplo de lo que él ha dispuesto para los bienaventurados en el Más Allá, donde no existe la muerte, ni se necesita restaurar ( $\mathrm{ramm}$ ) (Al-Maqqarī, Nafh: I, 566, Puerta Vílchez, 2004, p. 8) ${ }^{22}$.

Cada sarcófago y estatua, sin embargo, tendría también un significado propio y este es un trabajo que todavía está por hacer. Las escenas representadas en los sarcófagos y las estatuas fueron probablemente reinterpretadas y su significado cabe ser deducido y analizado a partir del lugar en el que se ubicaba la pieza en cuestión y del contexto en el que estaba inserta, es decir, el marco decorativo y arquitectónico del que formaba parte, el tipo de ceremonias o reuniones que se celebraban en ese lugar y lo que las fuentes escritas apuntan con respecto a los temas (políticos, culturales o religiosos) que eran de interés en la corte omeya.

La capacidad de los andalusíes para reconocer en estas antigüedades la imagen de una divinidad o un personaje de la antigüedad es una cuestión todavía por resolver. En Constantinopla no siempre se identificaba correctamente las estatuas clásicas y se confundían personajes históricos y mitológicos (Cameron y Herrin, 1984; Elvira Barba, 1987). En al-Ándalus esto habría sido aún más difícil. Pese a ello, sí contamos con algunas referencias interesantes en las que aparecen los nombres de Hércules y Venus.

El primero estaba presente en Madīnat al-Zahrā', -ya he mencionado el herma de Hércules-niño-y en el siglo $\mathrm{X}$ encontramos las primeras menciones relativas al héroe griego, identificado como un rey primitivo, conquistador de al-Ándalus y constructor de varios monumentos e ídolos que habrían delimitado el espacio peninsular, estableciendo sus fronteras geo-

22 La referencia tiene además un tono escatológico que encaja bien con el contexto andalusí de finales del siglo IX y comienzos del siglo $\mathrm{X}$ y el enfrentamiento político-religioso con los Fatimíes. Fierro, 2004. 
gráficas $^{23}$. En el caso de Venus, las referencias aluden al planeta y no a la diosa. Una noticia alude de hecho a una estatua (șuwara) en Madīnat al-Zahrā', que el califa almohade ordenó arrancar en el año 585$586 / 1190$. Al hacerlo, identifica la estatua como un talismán (tilasm) que representaba a Venus (Zuhara) de acuerdo con la opinión de la población cordobesa ${ }^{24}$. La referencia guarda relación con otras noticias del siglo $\mathrm{X}$ que aluden a la existencia de una estatua en una de las puertas de Madīnat al-Zahrā ${ }^{25}$. Además, la noticia puede relacionarse con una estatua real a la que aludí anteriormente: la cabeza de un retrato femenino procedente de la explanada frontera al Pórtico, una puerta ceremonial de ingreso al núcleo del palacio (Vallejo, 2010, pp. 178 y 262-263. Fig. 11). Por otro lado, llama la atención su condición de talismán (tilasm), algo que cabe vincular con el desarrollo de la astrología en al-Ándalus. En el Libro de las cruzes, la traducción castellana tardía del tratado de astrología andalusí, se señala que "los grados que son termino de Uenus en el signo de Virgo son ensennorados et apoderados en Cordova" (Libro de las cruzes, p. 160). Además, tal y como señaló M. Acién, la imagen de Zuhara evocaría la rivalidad político-religiosa con los Fatimíes del Norte de África (Acién, 1995, pp. 189-190), dado que dado que al-Zahrā' es justamente el apelativo que recibía Fātima, la hija del profeta Muhammad (Fierro, 2004, pp. 319 y 322).

En definitiva, estos dos ejemplos apuntan a que sin duda los sarcófagos y estatuas de Madinat al-Zahrā , tenían un significado propio y transmitían un discurso o narrativa de tipo político y religioso. Las imágenes pudieron ser reconocidas -quizás en el caso de Hércules- o más probablemente resignificadas en base a la tradición islámica y al contexto político y cultural -como parece ser el caso de Venus-. Las antigüedades no serían pues una "Alegoría de las Ciencias de los Antiguos", sino una referencia que permitía a los Omeyas definirse y legitimarse, dando un sentido al pasado, el presente y el futuro del islam, de al-Ándalus y de la comunidad islámica.

23 Orosio, Hist., I, pp. 2, 7 y 15, 1-9; K. Hurūšìūs, p. 21, no 15 y 78-79, no 297-298; Rasis, (Cap. LII-LIII); Al-Bakrī, K. almasālik, 470 y 1496/20; Al-Ḥimyarī, Rawḍ, pp. 448-9/174 y 177-178.

24 Ibn 'Iḍārī, Bayān, ed. Huici Miranda, 1953, pp. 158-159, trad. F. Maíllo, 1993, p. 64. Vallejo, 2010, pp. 178 y 262.

25 Ibn Ḥayyān, Muqtabis, trad. García Gómez, 1967, pp. 68 y 153; Ocaña, 1982, p. 453, nota 14

\section{CONCLUSIONES}

A lo largo de las páginas anteriores he trazado un panorama sobre la reutilización en al-Ándalus durante época omeya, es decir, desde el siglo VIII al siglo $\mathrm{X}$, incidiendo en qué, cómo y por qué se reutiliza y señalando paralelos en el mundo medieval cristiano e islámico cuando resulta posible.

He evidenciado que la reutilización de material es, casi siempre, un recurso constructivo, independientemente de su valor ideológico, que parece estar determinado por la disposición de estos materiales y por su empleo masivo, como se constata en la mezquita de Córdoba. Sin embargo, a este valor meramente constructivo y decorativo se le superpone a finales del siglo IX un valor discursivo, como antigüedad en sí misma, es decir, como "ruina" y "maravilla" capaz de evocar una reflexión sobre el pasado, el presente y el futuro. Este cambio resulta evidente en varios aspectos, siendo quizás el más destacado el control de estas antigüedades por parte de los emires y califas, algo que debe relacionarse también con una fetua emitida por el cadí cordobés Ibn Lubāba (m. 314/926) alusiva a la reutilización de materiales provenientes de cementerios, así como con el proceso de expansión urbana de Córdoba a comienzos del siglo X y con la colección de estatuas y sarcófagos de Madinnat al-Zahrā'.

Se podrían apuntar más ejemplos de reutilización y reinterpretación de antigüedades en el contexto andalusí, señalando piezas y estatuas que ilustrasen este cambio en el uso y el significado otorgado a las antigüedades, pero lo cierto es que el conjunto de piezas de Madīnat al-Zahrā' resulta ser el caso más extraordinario y, pese a ello, todavía carece de una explicación completamente satisfactoria. Sí conocemos la reutilización de los sarcófagos como pilas de agua, con un sentido eminentemente estético. Sin embargo, considerando que se trata de un conjunto de piezas único, cabe pensar que los sarcófagos y las estatuas tuvieron claro propósito ideológico de legitimación y valor discursivo. Habrían sido reinterpretados de acuerdo a la tradición coránica, en base a las fuentes clásicas conocidas y a la cultura astrológica de la época. Quizás las estatuas y sarcófagos representan aquellos personajes cuyas hazañas y virtudes eran dignas de ser conocidas o recordadas, modelos que imitar o repudiar, todo ello interpretado desde el prisma islámico y desde la óptica de los Omeyas que en el siglo $\mathrm{X}$, se consideraban claramente herederos del poder de los grandes soberanos universales y protectores y continuadores de la labor de los profetas de la tradición monoteísta. 


\section{FUENTES}

Ajbār Maŷmū'a (1867). Akhbār Majmū'a. Crónica anónima del siglo XI, ed. E. Lafuente. Madrid: Alcántara.

Al-Bakrī (1992). Kitāb al-Masālik wa-l-mamālik, ed. A. P Van Leeuwen y A. Ferré, 2 vols., Túnez: Al-Dar al'Arabiyya li-1-Kitab.[trad. parcial, E. Vidal Beltrán, (1982). Geografía de España (Kitāb al-Masālik wal-mamāik). Zaragoza: Anubar].Dikr bilad al-Andalus. Una descripción anónima de al-Andalus (1983). Ed. y trad. por L. Molina. Madrid: CSIC, 2 vols.,

Fath al-Andalus (1994). ed. Luis Molina. Madrid: CSIC. [trad. Penelas, M. (2002). La conquista de al-Andalus. Madrid: CSIC].

Al-Ḥimyarī (1975). Rawọ al-mi'ṭār, ed. I. Abbas. Beirut: Maktabat Lubnān. [ed. y trad. E. Lévi-Provençal, (1938). La Péninsule Ibérique au Moyen- Âge d'apres le Kitāb al-rawḍ al-mi'țār fì habar al-aktār d'Ibn 'Abd al-Mun'im al-Himyarī. Leiden: Brill.

Ibn al-Abbār (1995). Al-Takmila li-kitāb al-sila, ed. 'Abd al-Salam al-Harras. Casablanca: Dār al-Ma'rifa.

Ibn al-Atîr (1967-1969). Al-Kāmil fi at-Ta'rīj, ed. C. J. Tornberg. Beirut: Dar Sādir and Dār Bayrūt.

Ibn al-Qūtịya (1926). Ta'rīj iftitāḥ al-Andalus, ed. y trad. de Julián Ribera, Historia de la conquista de España de Abenalcotía el Cordobés. Seguida de fragmentos históricos de Abencotaiba. Madrid: Real Academia de la Historia.

Ibn Ḥayyān (2001). Muqtabis II-I, Crónica de los emires Alhakam I y Abdarrahman II entre los años 796 y 847 [Almuqtabis II-1], trad. de M. A. Makkī y F. Corriente. Zaragoza: Anubar.

Ibn Ḥayyān (1967). Muqtabis VII: El califato de Córdoba en el "muqtabis" de Ibn Hayyān. Anales palatinos del califa de Córdoba al-Hakam II, por 'İsà b. Ahmad al-Rāzi 971-975, trad. E. García Gómez. Madrid: Sociedad de Estudios y Publicaciones.

Ibn 'Id̄ārī (1948-1951). Kitāb al-bayān al-mugrib fì ajbārr al-Andalus wa l-Magrib, ed. G. S. Colin y E. LéviProvençal. Leiden: Brill.

Ibn 'I d̄ārī (1953). Kitāb al-bayān, Los Almohades, trad. A. Huici Miranda. Tetuán: Editora Marroquí.

Ibn 'Idārī (1993). La caída del Califato de Córdoba y los Reyes de Taifas, trad. F. Maíllo. Salamanca: Universidad de Salamanca.

Ibn al-Jawzī (1938). Al-Muntazam. Hyderabad: Matbaah Da'irat al-Ma'ārif al-’Uthmāniyyah.

Kitāb Hurūšiyūs: traducción árabe de las "Historiae adversus paganos" de Orosio (2001). edición de M. Penelas. Madrid: CSIC.

Libro de las Cruzes (1961). Kasten, L1. A. y Kiddle, L. B. (eds.). Madrid/Madison: CSIC.

Al-Maqqarī (1968). Nafh al-ṭ̂̀b min gusn al-Andalus alratīb, ed. I. Abbas. Beirut: Dār Șādir.

Al-Maqrīzī (1911). Kitāb al-Mawā'iz wa-l-i tibār fì dikr al-jițat wa-l-ātāâr (Al-jițaț), ed. G. Wiet. El Cairo: Impr. de l'Inst. Français d'Archéologie Orientale.
Orosio (1990). Historiae adversus paganos. Histoires (contre les Païens), ed. y trad. por M. ${ }^{\text {a-P. Arnaud- }}$ Lindet. Paris: Les belles lettres.

Al-Qazwīnī (1917). The geographical part of the Nuzhatal-qulub: composed by Hamd Allah Mustawf of Qazwīn in in 740 (1340), trad. G. Le Strange. Leiden/ London: Brill.

Rasis (1975). Crónica del moro Rasis, versión del ajbār mulūk al-Andalus de Ahmad ibn Muhammad ibn Mūsà al-Rāzī, 889-955. Romanzada para el rey don dionis de Portugal hacia el 1300 por Mahomad, Alarife y Gil Pérez, clérigo de don perianes porçel, ed. D. Catalán y M. Soledad De Andrés. Madrid: Cátedra.

Al-Wanšarīsī (1981-1983). al-Mi'yār al-mu'rib, ed. de M. Haŷŷ̄i et al., 13 vols., Rabat-Beirut: Wizārat al-Awqāf, Dār alGarb al-Islāmī.

\section{BIBLIOGRAFÍA}

Acién Almansa, M. (1995). "Materiales e hipótesis para una interpretación del Salón de Abd al- Rahman al-Nasir". Vallejo, A. (coord.), Madinat al-Zahara: El Salón de Abd alRahman III. Córdoba: Universidad de Córdoba, pp. 177-195.

Acién Almansa, M. y Vallejo Triano, A. (1998). "Urbanismo y Estado islámico. De Córdoba a Qurțuba-Madīnat alZahrā’”. En: Cressier, P., García-Arenal, M. y Méouak, M. (Eds.). Genèse de la ville islamique en al-Andalus et au Maghreb occidental. Madrid: Casa de Velázquez, pp. 107-136.

Alba Calzado, M. (2001). “Mérida, entre la Tardoantigüedad y el Islam: datos documentados en el Área Arqueológica de Morería". Cuadernos emeritenses, 17, pp. 265-307.

Alba Calzado, M. (2004). "Evolución y final de los espacios romanos emeritenses a la luz de los datos arqueológicos (pautas de transformación de la ciudad Tardoantigua y Altomedieval)". En: Nogales Basarrate, T. (Ed.). Augusta Emerita: Territorios, Espacios, Imágenes y Gentes en Lusitania Romana. Mérida: Museo Nacional de Arte Romano, pp. 207-255.

Alba Calzado, M. (2009). "Los edificios emirales de Morería (Mérida), Una muestra de arquitectura del poder". Anales de Arqueología Cordobesa, 20, pp. 379-420.

Alba Calzado, M. y Feijoo, S. (2005). "Defensas urbanas de la Mérida islámica". En: Gómez Martínez, S. (Coord.). Al-Andalus, espaço de mudança, Balanço de 25 anos de historia e arqueologia medievais, Homenagem a J. Zozaya Stabel-Hansen. Mértola: Campo Arqueológico de Mértola, pp. 101-110.

Azuar, R. (2005). "Las técnicas constructivas en la formación de al-Andalus". Arqueología de la arquitectura, 4, pp. 149-160.

DOI: https://doi.org/10.3989/arq.arqt.2005.80

Beltrán Fortes, J. (1988-1990). "La colección arqueológica de época romana aparecida en Madinat al-Zahra". Cuadernos de Madīnat al-Zahrā', 2, pp. 109-126.

Beltrán Fortes, J. (1993). "Hermeraclae hispanos". En: Estudios dedicados a Alberto Balil. In memorian. Málaga: Universidad de Málaga, pp. 163-174. 
Beltrán Fortes, J. (1999). Los sarcófagos romanos de la Bética con decoración de tema pagano. Málaga: Universidad de Málaga.

Beltrán Fortes, J., García García, M. A. y Rodríguez Oliva, P. (2006). Corpus signorum imperii Romani. Corpus de esculturas del Imperio romano. España, 1, 3. Los sarcófagos de Andalucía. Murcia: Tabularium.

Bermúdez Cano, J. M. (1993). "La trama viaria propia de Madīnat al-Zahrā' y su integración con la de Córdoba". Anales de Arqueología Cordobesa, 4, pp. 259-294. DOI: https://doi.org/10.21071/aac.v0i.11386

Caballero, L. y Utrero, M. ${ }^{\text {a }}$ A. (2013). "El ciclo constructivo de la alta Edad Media hispánica. Siglos VIII-X". Archeologia dell'architettura, 18, pp. 127-146.

Calvo Capilla, S. (2012). "Madīnat al-Zahrā' y la observación del tiempo. El renacer de la Antigüedad Clásica en la Córdoba del siglo X". Anales de Historia del Arte, 22/ II, pp. 131-160.

DOI: https://doi.org/10.5209/rev_anha.2013.v23.41563

Calvo Capilla, S. (2013). "Ciencia y 'adab' en el islam. Los espacios palatinos dedicados al saber". Anales de Historia del Arte, 23/II, pp. 51-78.

DOI: https://doi.org/10.5209/rev_anha.2013.v23.42831

Calvo Capilla, S. (2014). "The Reuse of Classical Antiquity in the Palace of Madinat al-Zahrā' and Its Role in the Construction of Caliphal Legitimacy". Muqarnas, 31/1, pp. 1-33.

DOI: https://doi.org/10.1163/22118993-00311p02

Cameron, A. y Herrin, J. (1984). Constantinople in the Early Eight Century: The Parastaseis Syntomoi Chronikai: Introduction, Translation and commentary. Leiden: Brill.

Castro, E. (2005). El arrabal de época califal de la zona arqueológica de Cercadilla: la arquitectura doméstica. Monografías de Arqueología Cordobesa, 12. Córdoba: Universidad de Córdoba.

Cómez Ramos, R. (1994). "Fragmentos de una mezquita sevillana: la aljama de Ibn Adabbas". Laboratorio de Arte, 7, pp. 11-23.

Cressier, P. (1984). "Les chapiteaux de la grande Mosquée de Cordoue (oratoires d' 'Abd al-Raḥmān I et d' 'Abd al-Raḥmān II) et la scuplture de chapiteaux à l'époque émirale. Première partie". Madrider Mitteilungen, 25, pp. 216-281.

Cressier, P. (1985). "Les chapiteaux de la grande Mosquée de Cordoue (oratoires d' 'Abd al-Raḥmān I et d' 'Abd al-Raḥmān II) et la scuplture de chapiteaux à l'époque émirale. Deuxième partie", Madrider Mitteilungen, 26, pp. 257-313.

Cressier, P. (1991). "El renacimiento de la escultura de capiteles en la época emiral: entre Occidente y Oriente". Cuadernos de Madinat al-Zahrā', 3, pp. 165-187.

Cressier, P. (2001). "El acarreo de obras antiguas en la Arquitectura islámica de primera época". Cuadernos emeritenses, 17, pp. 309-334.

Cressier, P. (en prensa): "Fatimíes de Ifrîqiya y Omeyas de al-Andalus: dos formas de contemplar y de reutilizar el patrimonio arquitectónico antiguo". En: Márquez, C. (Ed.). MÍMESIS: Imitación de los modelos clásicos y nuevos valores semánticos en el mundo tardoantiguo y medieval. Córdoba: Universidad de Córdoba.

Cressier, P. y Rammah, M. (2006). "Sabra al-Mansuriya. Une nouvelle approche archéologique", Comptes rendus des séances de l'Académie des Inscriptions et Belles-Lettres, 150 e année, 1, pp. 630-631.

De la Barrera, J. L. 1984: Los capiteles romanos de Mérida. Monografías emeritenses, 2. Badajoz: Museo Nacional de Arte Romano.

El Daly, O. (2005). Egyptology: The Missing Millennium, Ancient Egypt in Medieval Arabic Writings. London: UCL Press.

Elices Ocón, J. (2020). Respeto o barbarie: el islam ante la Antigüedad. De al-Andalus a DAESH. Madrid: Marcial Pons.

Elices Ocón, J. y Manzano Moreno, E. (2019): "Uses of the Past in Early Medieval Iberia (eighth-tenth centuries)". Medieval Worlds, 10, pp. 87-106. DOI: https://doi.org/10.1553/medievalworlds_ no10_2019s87

Elvira Barba, M. A. (1987). "Las estatuas animadas de Constantinopla". Erytheia: Revista de estudios bizantinos y neogriegos, 8 (1), pp. 99-115.

Ewert, E. (2009). "Spolien, ihre islamischen Nachschöpfungen und ihre Musterschemata in den Hauptmoscheen von Córdoba und Qayrawān". En: Schattner, Th. G. y Valdés Fernández, F. (Eds.). Spolia en el entorno del poder/Spolien im Umkreis der Macht, Actas del coloquio. Toledo del 21 al 22 de septiembre 2006. Madrid/Mainz: Deutsches Archäologisches Institut Abteilung, pp. 287-304.

Ewert, C. y Wisshak, J.-P. (1981). Forschungen zur almohadischen Moschee I. Vorstufen: Hierachische Gliederungen westislamischer Betsäle des 8. bis 11 . Jahrhunderts: Die Hauptmoscheen von Qairawan und Córdoba und ihr Bannkreis. Madrid/Mainz: Deutsches Archäologisches Institut Abteilung.

Fernández Ochoa, C., Bendala Galán, M., García Entero, V. y Vidal Álvarez, S. (2011). "Cubierta de sarcófago con el ciclo de Jonás hallada en Carranque (Toledo)". Archivo Español de Arqueología, 84, pp. 229-240.

DOI: https://doi.org/10.3989/aespa.084.011.009

Fierro, M. (2004). "Madinat al-Zahara', el paraíso y los fatimíes". Al-Qantara 25, 2, pp. 299-328.

DOI: https://doi.org/10.3989/alqantara.2004.v25.i2.135

Finster, B. (2009). "Die Werwendung von Spolien in umayyadischer Zeit". En: Schattner, T. G. y Valdés Fernández, F. (Hrsg.). Spolien im Umkreis der Macht/Spolia en el entorno del poder, Actas del coloquio. Toledo del 21 al 22 de septiembre de 2006. Madrid/Mainz: Deutsches Archäologisches Institut Abteilung, pp. 273-286.

Fontaine, J. (1947). "Un sarcófago cristiano de Córdoba, coetáneo de Osio". Archivo Español de Arte y Arqueología, 20, pp. 96-121.

García y Bellido, A. (1959). "El sarcófago romano de Córdoba”. Archivo Español de Arqueologia, 32 (99-100), pp. 3-37.

García García, M. A. (2004). "La reutilización y destrucción de los sarcófagos romanos de Baetica durante la edad media”. Romula, 3, pp. 239-256. 
González Gutiérrez, C. (2012). Las mezquitas de barrio de "Madinat Qurtuba": una aproximación arqueológica. Córdoba: Diputación de Córdoba.

González Gutiérrez, C. (2015). Las mezquitas de la Córdoba Islámica: concepto, tipología y función urbana. Tesis doctoral. Universidad de Córdoba.

González Gutiérrez, C. (2016). "Las mezquitas de barrio de Madınat Qurtubat 15 años después: espacios religiosos urbanos en la capital andalusí”. Anales de Arqueología Cordobesa, 27, pp. 267-292.

Greenhalgh, M. (2009). Marble past, monumental present: building with antiquities in the medieval Mediterranean. Leiden: Brill.

Greenhalgh, M. (2012). Constantinople to Córdoba: Dismantling Ancient Architecture in the East, North Africa and Islamic Spain. Leiden: Brill.

Gurriarán Daza, P. (2004). "Hacia una construcción del poder. Las prácticas edilicias en la periferia andalusí durante el Califato". Cuadernos de Madīnat al-Zahrā', 5, pp. 297-325.

Hernández Juberías, J. (1996). La península imaginaria: mitos y leyendas sobre al-Andalus. Madrid: CSIC.

Hidalgo, R. (1996). Espacio público y espacio privado en el conjunto palatino de Cercadilla (Córdoba): el aula central y las termas. Sevilla: Consejería de Cultura.

Jacobs, I. (2020). "Old statues, new meanings. Literary, epigraphic and archaeological evidence for Christian reidentification of statuary". Byzantinische Zeitschrift, $113,3,789-836$

DOI: https://doi.org/10.1515/bz-2020-0035

Kinney, D. (2001). "Roman Architectural Spolia". Proceedings of the American Philosophical Society, 145, 2, pp. 138-150.

Kristensen, T. M. (2013). Making and Breaking the gods: Christian Responses to Pagan Sculpture in Late Antiquity. Aarhus: Aarhus University Press.

Labarta, A., Barceló, C. y Veglison, J. (2011). València àrab en prosa $i$ vers, Valencia: Universidad de Valencia.

Lagardère, V. (1995). Histoire et société en Occident musulman au Moyen Age. Analyse du Mi'yār d'al Wanšarīsī. Madrid: Casa de Velázquez.

León Muñoz, A. (2018). "Técnicas constructivas mixtas en piedra en la Córdoba omeya". Arqueología de la Arquitectura, 15, e078. DOI: https://doi.org/10.3989/arq.arqt.2018.022

Luna, D. y Zamorano, A. (1999). "La mezquita de la antigua finca El Fontanar (Córdoba)". Cuadernos de Madinat al-Zahrā', 4, pp. 145-173.

Mahfoudh, F. (2011). "Fiqh et réemploi en Ifriqiya et au Maghreb”. En: 711-2011. Treize siècles d'histoire partagée. Essai de bilan et perspectives d'avenir. Actes du colloque international tenu à l'université de Tlemcen du 17 au 19 octobre 2011. Tlemcen: Université de Tlemcen, pp. 57-65

Manzano Moreno, E. (2006). Conquistadores, Emires y Califas. Los omeyas y la formación de al-Ándalus. Barcelona: Crítica.

Manzano Moreno, E. (2019): La corte del califa: Cuatro años en la Córdoba de los Omeyas. Barcelona: Crítica.
Molina, L. (1982-1983). "Sobre la procedencia de la Historia preislámica inserta en la Crónica del moro Rasis". Awraq, V-VI, pp. 133-139.

Montejo Córdoba, A. J. y Garriguet Mata, J. A. (1998). “El Alcázar andalusí de Córdoba: estado actual de la cuestión y nuevas hipótesis". I Congreso Internacional Fortificaciones en Al-Andalus. Algeciras, 1996. Algeciras: Ayuntamiento de Algeciras, pp. 303-332.

Moráis Morán, J. A. (2017). "La «construcción» del pasado a través de la memoria de los muertos: los sarcófagos de Fernán González y doña Sancha". En: Freixa, M. (Dir.). XVII Congreso Nacional de Historia del Arte. Barcelona, 2008. Barcelona: Atrio/ Universidad de Barcelona, pp. 717-733.

Moralejo, S. "La reutilización e influencia de los sarcófagos antiguos en la España medieval". En: B. Andrea y S. Settis (Eds.). Colloquio sul reimpiego dei sarcofagi romani nel Medioevo. Marburg/Lahn, 1982, 187-203.

Morán Turina, M. (2010). La memoria de las piedras: anticuarios, arqueólogos y coleccionistas de antigüedades en la España de los Austrias. Madrid: Centro de Estudios Europa Hispánica.

Northedge, A. (2008). The Historical Topography of Samarra. London: British School of Archaeology in Iraq.

Ocaña, M. (1970). El cúfico hispano y su evolución. Madrid: Instituto Hispano-Arabe de Cultura.

Ocaña, M. (1982). “Algo más sobre la 'Bāb al-Șūra' de Córdoba”. Al-Qantara, III, pp. 447-455.

Peña, A. (2009). "Análisis del reaprovechamiento de material en la Mezquita Aljama de Córdoba”. Schattner, Th. G. y Valdés Fernández, F. (Eds.). Spolia en el entorno del poder/Spolien im Umkreis der Macht, Actas del coloquio. Toledo del 21 al 22 de septiembre 2006. Madrid /Mainz: Deutsches Archäologisches Institut Abteilung, pp. 247-272.

Peña, A. (2010). Estudio de la decoración arquitectónica romana y análisis del reaprovechamiento de material en la Mezquita Aljama de Córdoba. Córdoba: Universidad de Córdoba.

Puerta Vílchez, J. M. (2004). "Ensoñación y construcción del lugar en Madinat al Zahra". En: Roldán Castro, F. (Ed.). Paisaje y naturaleza en al-Andalus. Sevilla: Universidad de Sevilla, pp. 313-338.

Rubiera Mata, M. ${ }^{\mathrm{a}}$ J. (1981). La arquitectura en la literatura árabe. Madrid: Hiperión.

Sánchez Ramos, I. (2010). Corduba durante la Antigüedad tardía. Las necrópolis urbanas. Oxford: Archaeopress.

Schnapp, A. (2007). "Vestigios, monumentos y ruinas: Oriente frente a Occidente". En: El Gabinete de Maravillas, Cuadernos de la Fundación M. Botín, Observatorio de Análisis de tendencias. Santander: Editorial, pp. 21-52.

Schnapp, A. (ed.) (2013). World Antiquarianism: comparative perspectives. Los Angeles: Getty Research Institute.

Shaw, W. (2003). Possessors and Possessed. Museums, Archaeology, and the Visualization of History in the Late Ottoman Empire. Berkeley/Los Angeles: University of California Press. 
Sotomayor Muro, M. (1973). Datos históricos sobre los sarcófagos romano-cristianos de España. Granada: Universidad de Granada.

Sotomayor Muro, M. (2000). "Dos nuevos fragmentos de sarcófagos paleocristianos en Córdoba". Anales de Arqueología Cordobesa, 11, pp. 275-288.

Stirling, L. (2015). "The Opportunistic Collector: Sources of Statuary Décor and the Nature of Late Antique Collecting". En: Wellington Gahtan, M. y Pegazzano, D. (Eds.). Museum Archetypes and Collecting in the Ancient World. Leiden: Brill, pp. 137-145.

Stylow, A. U. (2000). "Nuevo gobernador de la Bética del siglo IV”. Gerión, 18, pp. 425-437.

Torres Calzada, K. (2014). "El emeritense. Noticia de la ciudad de Mérida recogida en el Iqtibās al-anwār de Abū Muḥammad al-Rušāțī (466/1074-542/1147)". Miscelánea de Estudios Árabes y Hebraicos. Sección Árabe-Islam, 63, pp. 233-256.

Utrero Aguado, M. Á. y Sastre de Diego, I. (2012). "Reutilizando materiales en las construcciones de los siglos VII-X. ¿Una posibilidad o una necesidad?'. Anales de Historia del Arte, 22 (Núm. Especial II), pp. 309-323. DOI: https://doi.org/10.5209/rev_anha.2013.v23.41575
Vallejo Triano, A. (2010). La ciudad califal de Madinat alZahrā': arqueología de su arquitectura. Córdoba: Almuzara.

Vallejo Triano, A. (en prensa): "Materiales de la Antigüedad en Madīnat al-Zahrā"”. En: Márquez, C. (Ed.). MÍMESIS: Imitación de los modelos clásicos y nuevos valores semánticos en el mundo tardoantiguo y medieval. Córdoba: Universidad de Córdoba.

Valor Piechotta, M. (1993). "La mezquita de Ibn Adabbas de Sevilla. Estado de la cuestión”. Estudios de Historia y Arqueología medievales, 9, pp. 299-314.

Vaquerizo, D. y Murillo, J. (eds.) (2010). El anfiteatro romano de Córdoba y su entorno urbano. Análisis arqueológico (ss. I-XIII d.C.). Córdoba: Universidad de Córdoba.

Vidal Castro, F. (1993). "El Mi'yār de al-Wanšarīsī (m. 914/1508). I: fuentes, manuscritos, ediciones, traducciones". Miscelánea de estudios árabes y hebraicos. Sección Árabe-Islam, 42, pp. 317-361.

Vidal Castro, F. (1995). "El Mi yār de al-Wanšarisi (m. 914/1508). II: Contenido”. Miscelánea de estudios árabes y hebraicos. Sección Árabe-Islam, 44, pp. 213-246.

Webb, P. (2014). "Al-ȳāhiliyya: Uncertain Times of Uncertain Meaning”. Der Islam, 91 (1), pp. 69-94.

DOI: https://doi.org/10.1515/islam-2014-0005 